\title{
Millennial-scale Holocene hydrological changes in the northeast Atlantic: New insights from 'La Grande Vasière' mid-shelf mud belt
}

\author{
Meryem Mojtahid,' Matthieu Durand,' Pierre-Olivier Coste, ',2 \\ Samuel Toucanne, ${ }^{3}$ Hélène Howa, ${ }^{1}$ Jean Nizou, ${ }^{3}$ \\ Frédérique Eynaud ${ }^{4}$ and Aurélie Penaud ${ }^{2}$
}

\begin{abstract}
A mid- to late-Holocene paleohydrological reconstruction from the northeast Atlantic is proposed through the study of a high-resolution sedimentary record from the northern continental shelf of the Bay of Biscay (BoB). Three foraminiferal species dominate the assemblages with Rosalina globularis showing an overall decrease in absolute and relative abundances from $\sim 7$ to 0.4 cal. ka BP, whereas the opposite trend is observed for Cibicides refulgens and Lobatula. These long-term patterns are interpreted as a response to the overall cooling trend and/or the progressive deepening of the water column because of the relative sea-level (RSL) rise. Foraminiferal $\delta^{18} \mathrm{O}$ and grain-size analyses show a significant shift around 3.5-2.5 cal. ka BP toward a heavier isotopic signature and finer sediments. We mainly link this change to enhanced contribution of continental freshwaters and fine sediments after the near-stabilization of the RSL rise. By reducing coastal accommodation spaces, this led to a better channelization of river outflows and probably to the formation of the modern winter thermohaline front. Superimposed on these long-term patterns, our data highlight strong millennial-scale variability ( 1250 -year peak). Such cyclicity is consistent with several records tracing changes in rainfall and storminess regimes in northern Europe, and the dynamics of the subpolar gyre (SPG). We suggest a millennial time-scale control of a NAO-like (North Atlantic Oscillation) climatic process modulating continental humidity (and the associated river discharges) and SPG dynamics through wind stress. Spectral analyses reveal an additional 500 -year frequency peak implying a possible solar forcing.
\end{abstract}

\section{Keywords}

AMOC, Bay of Biscay, benthic foraminifera, NAO-like process, river runoff, stable isotopes

Received 5 July 2018; revised manuscript accepted 30 October 2018

\section{Introduction}

Holocene continental shelf deposits in the Bay of Biscay (BoB) have the potential to capture both continental and open marine signals (e.g. Durand et al., 2018; Garcia et al., 2013; Mojtahid et al., 2013; Naughton et al., 2007). The continental signal originates mainly from the Dordogne and Garonne Rivers (referred to in the following as the Gironde Rivers) and the Loire River (Figure 1a). Their runoff is conditioned by rainfall regimes over their catchment areas (Figure 1a). The marine signal is captured because the oceanic circulation in the $\mathrm{BoB}$ is under the influence of a branch of the North Atlantic Current (NAC). The modern variability of the Atlantic Meridional Overturning Circulation (AMOC) and the associated inflow from the NAC to higher latitudes are of great importance in modulating climate over Europe (e.g. Clark et al., 2002; Jackson et al., 2015; Staines-Urías et al., 2013; Thornalley et al., 2009). Particularly, the expansion/contraction of the North Atlantic subpolar gyre (SPG) modulates the exchange of heat, salinity, and freshwater with the Nordic seas (Born and Stocker, 2014; Häkkinen and Rhines, 2004), thus preconditioning the strength of the AMOC through the production of deep and intermediate water masses (e.g. Hátún et al., 2005; Sherwin et al., 2012; Yong-Qi and Lei, 2008). Along the French
Atlantic coast, the slowing down of the relative sea-level (RSL) rise from middle to late Holocene (García-Artola et al., 2018; Goslin et al., 2015) led to the reduction of coastal accommodation spaces, which in turn influenced the export of freshwaters and sediments to the ocean (Clavé et al., 2001; Durand et al., 2016; Spencer et al., 1998). In addition, internal and external climate forcing influenced the runoff of the French rivers as well as the strength of the AMOC. It is fairly well known that rainfall over Europe is governed, besides local hydrometeorological control, by oscillating internal climatic forcing such as the North Atlantic

'LPG-BIAF, UMR-CNRS 6I I 2, University of Angers, France 2University of Brest and Laboratoire Géosciences Océan, CNRS UMR 6538, Institut Universitaire Européen de la Mer, France

${ }^{3}$ Laboratoire Géodynamique et enregistrement Sédimentaire, IFREMER, France

4UMR CNRS 5805 EPOC (Environnements et Paléoenvironnements

Océaniques et Continentaux), University of Bordeaux, France

\section{Corresponding author:}

Meryem Mojtahid, LPG-BIAF, UMR-CNRS 6I I2, University of Angers, UFR Sciences, 2, Bd Lavoisier, 49045 Angers Cedex 0I, France. Email: meryem.mojtahid@univ-angers.fr 


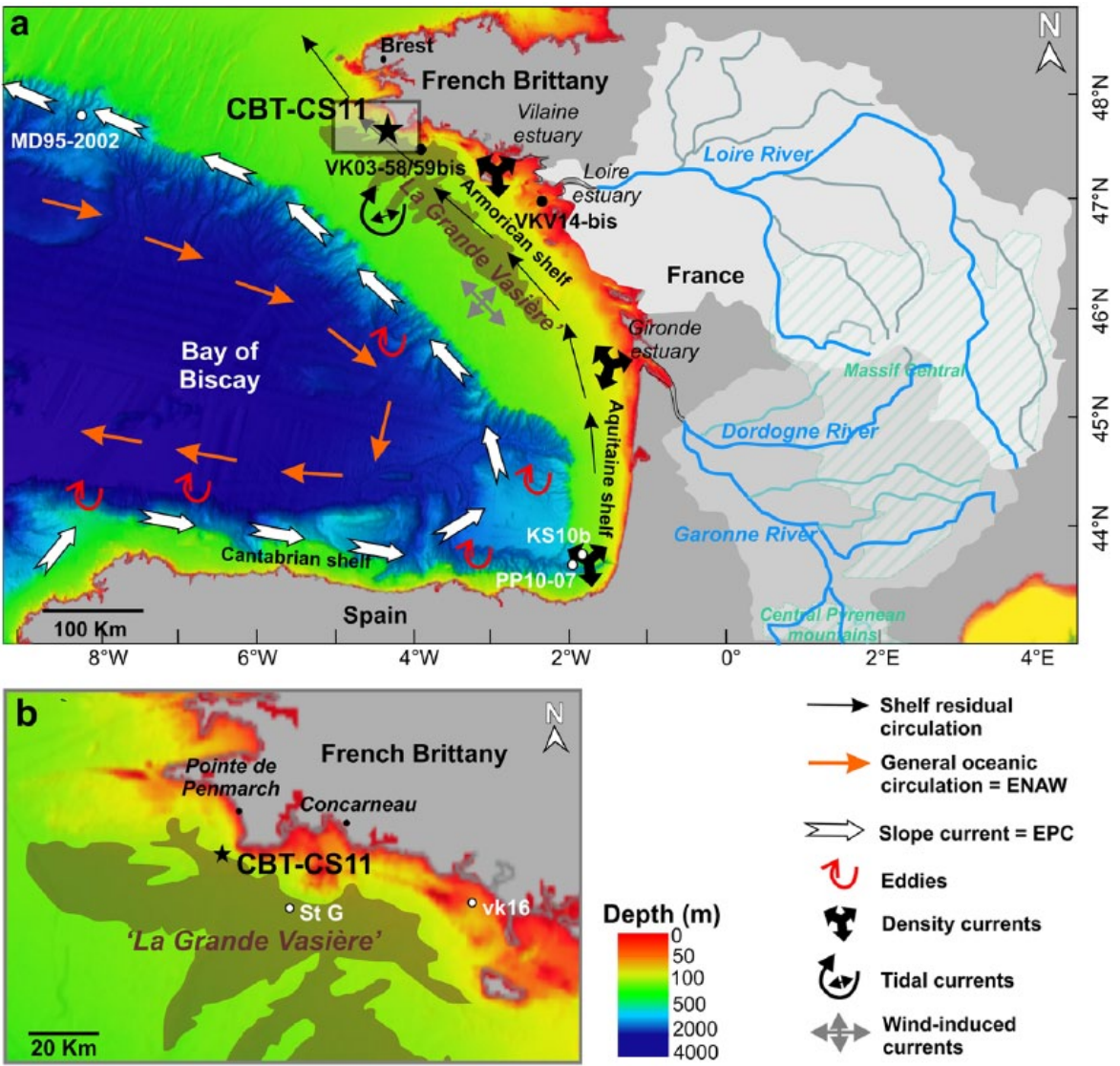

Figure I. (a) A map illustrating the general surface circulation of the BoB (Koutsikopoulos and Le Cann, 1996) and the extent of the Loire and Gironde catchment areas. The locations of core CBT-CSII (this study) and the other cited cores in the text are indicated:VK03-58/59bis (Naughton et al., 2007); KVI4-bis (Durand et al., 20I8); ProsecanKSI0b (Mojtahid et al., 20I3); PPI0-07 (Brocheray et al., 20I4). Map performed using the online EMODnet Portal for Bathymetry (http://www.emodnet-bathymetry.eu/); (b) zoom on the study site, and the location of the nearby cores St G (Duchemin et al., 2008) and vkl6 (Estournès et al., 20I2). ENAW: Eastern North Atlantic Water; EPC: European Poleward Current.

Oscillation (NAO) (Hurrell, 1995; Hurrell et al., 2001; Labat, 2008). Several studies indicate that the hydrological variability of the main French watersheds (Seine, Loire, Garonne, and Rhône) has a high degree of coherence with the NAO (Chevalier et al., 2014; Milliman, 2001; Shorthouse and Arnell, 1997). Other studies are more doubtful about the dominant effect of the NAO on the hydrology of the French rivers and/or evoke probable connections with other climatic mechanisms such as the AMO (Atlantic Multidecadal Oscillation) and EAP (Eastern Atlantic Pattern) (e.g. Boé and Habets, 2014; Costoya et al., 2017). The study of Tréguer et al. (2014) reveals that the modern variability (AD 1998-2013 period) in sea surface temperature (SST) in coastal waters of Brittany is connected to the NAO while the EAP exerts a major influence on discharges of the adjacent rivers. Meanwhile, at annual, decadal to probably millennial time-scales, the NAO is also known as the dominant mode of climate variability controlling the intensity of winter westerlies across the North Atlantic (Hurrell, 1995; Hurrell et al., 2008; Fletcher et al., 2012; Thompson et al., 2003; Wanner et al., 2008). Typically, in the northern North Atlantic, stronger westerly winds (typical of a positive NAO state) increase the depth of the mixed-layer and strengthen the SPG (Sarafanov, 2009; Sarafanov et al., 2010). Superimposed on this internal climatic forcing, solar activity has also a major imprint on Holocene climate variability (e.g. Debret et al., 2009; Soon et al., 2014).

Here, we investigate Holocene variability as recorded in sediments from the mid-shelf mud belt 'La Grande Vasière' (south of the tip of the French Brittany; Figure 1), in response to global (e.g. AMOC dynamics, NAO-like processes, solar forcing) and regional forcing (e.g. sea-level rise, continental inputs). We use benthic foraminiferal assemblages and stable isotopes measured on their shells supplemented by grain-size x-ray fluorescence (XRF) analyses. Several studies based on a similar multi-proxy approach have been conducted successfully in various marginal environments to track Holocene variability (e.g. Bartels-Jónsdóttir et al., 2006; Mojtahid et al., 2015; Polyak et al., 2002; Xiang et al., 2008), but only very few have been performed in the BoB because of the generally low preservation of Holocene sediments (Durand et al., 2018; Garcia et al., 2013; Mojtahid et al., 2013). One of the main interests of our study is that the exceptional sedimentation rate $\left(\sim 70 \mathrm{~cm} \mathrm{ka}^{-1}\right)$ characterizing our coring site (a depocenter of fine sediments; Dubrulle et al., 2007) permits studying the past $\sim 7 \mathrm{kyr}$ at a high time-resolution ( $\sim 19-130$ years), unprecedented in the BoB. This allows robust spectral analyses, which highlight for the first time in marine sediments from the $\mathrm{BoB}$ a clear millennial variability, linking our local record to larger scale mechanisms such as North Atlantic hydrological patterns.

\section{Study area}

\section{Sedimentary characteristics}

'La Grande Vasière' is a mid-shelf mud belt (McCave, 1972) extending over more than $225 \mathrm{~km}$ long and $40 \mathrm{~km}$ wide on the Armorican shelf between 80 and $110 \mathrm{~m}$ water depth (Lesueur et al., 2001) (Figure 1). Characterizing it as a mud belt is, however, not entirely satisfactory because it has been described as a thin and broken blanket of muddy sands in which the silt and clay content does not exceed 30\% (Lesueur et al., 2001). The quaternary sequence of the Armorican continental shelf starts with a 


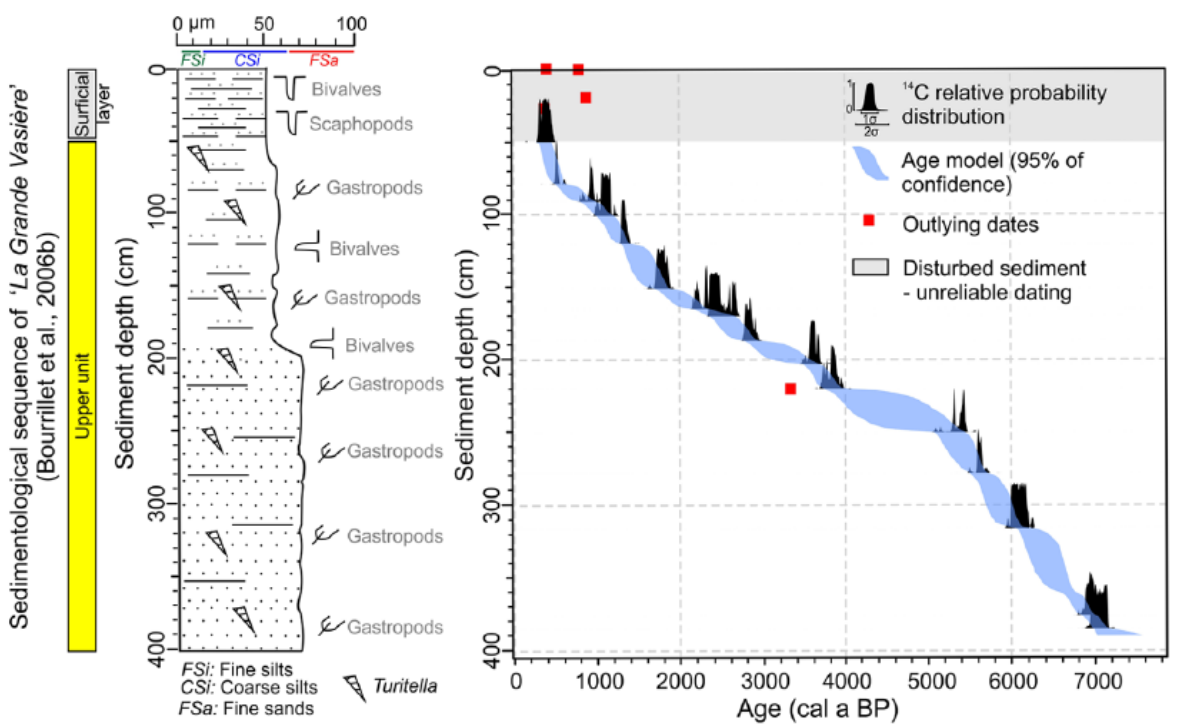

Figure 2. Synthetic sedimentological log and age model of core CBT-CSII.

regional erosion surface inherited from river incisions of Eocene limestones during an early Pleistocene regression $(\sim 700-500 \mathrm{ka}$ BP; Proust et al., 2001). This sequence is subdivided into (a) the 'lower unit' which consists of several meters of bioclastic coarse to medium sands deposited in a $\sim 0-50 \mathrm{~m}$ water depth range, (b) the 'upper unit' which consists of several meters of coarse silts to fine gray sands deposited in a $\sim 50-100 \mathrm{~m}$ water depth range (Andreieff et al., 1971), and (c) the 'surficial layer' which consists of few decimeters of muddy and bioturbated silts (Bourillet et al., 2006b). The two upper units, that concern our sediment core (Figure 2), form the mud belt 'La Grande Vasière' and were deposited over the past $\sim 9$ kyr BP (Bourillet et al., 2006a; Naughton et al., 2007) in a context of three major phases of RSL rise (Goslin et al., 2015): (a) a relatively rapid increase between $\sim 8$ and $\sim 5.5 \mathrm{cal}$. ka BP ( -10 and $-3 \mathrm{~m} \mathrm{RSL}$ ), (b) a near-stabilization between $\sim 5.5$ and $\sim 2.5$ cal. ka BP (around $-3 /-2 \mathrm{~m} \mathrm{RSL}$ ), and (c) a slight rise in the most recent period. In a context of RSL high stand, such as since $\sim 5.5 \mathrm{cal}$. ka BP, major sources of fine sediments (silts and clays) to 'La Grande Vasière' are fluvial supplies carried in suspension, essentially from the Loire and Gironde Rivers and, to a lesser extent, from the Adour, Vilaine, and Charente Rivers (Guillaud et al., 2008; Jouanneau et al., 1999). Today, the sandy fraction is mainly sourced from coastal erosion occurring mostly during winter storm events, whereas direct sandy fluvial contributions are considered negligible (Castaing and Jouanneau, 1987). In our core, the continuous sedimentation $\left({ }^{14} \mathrm{C}\right.$ chronological coherency) and the absence of erosion surfaces, especially in the first half of the record dominated by fine sands (Figure 2), may point out to either a non-negligible direct fluvial input at the time or to distal tempestite deposits characterized by fine sands and weakly developed erosional surfaces (Aigner, 1985).

\section{Surface circulation in the $B o B$}

The central part of the BoB is influenced by the Eastern North Atlantic Water (ENAW) transported by the NAC following an anticyclonic circulation (Charria et al., 2013; Pingree, 1984; Pollard and $\mathrm{Pu}, 1985$; Figure 1a). The circulation becomes cyclonic along the continental slope during autumn and winter with the European Poleward slope Current (EPC) transporting northward ENAW of subtropical origin (Garcia-Soto and Pingree, 2012) (Figure 1a). The EPC, which flows from the surface to $1000 \mathrm{~m}$ depth along the continental slope, turns equatorward in summer (Charria et al., 2013). The slope boundary flow appears unstable, particularly where there are abrupt changes in topography (Pingree and Le Cann, 1992a). This results in the intrusion of slope waters into the central $\mathrm{BoB}$ and the consequent formation of surface-intensified meso-scale structures ( $\sim 100 \mathrm{~km}$ in diameter) called SWODDIES for Slope Water Oceanic eDDIES (Dickson and Hughes, 1981; Koutsikopoulos and Le Cann, 1996; Madelain and Kerut, 1978; Pingree and Le Cann, 1992b) (Figure 1a). Over the shelf, weak currents occur from April to September $\left(<2.5 \mathrm{~cm} \mathrm{~s}^{-1}\right)$ and a poleward circulation takes place from October to March with intense currents reaching $10-15 \mathrm{~cm} \mathrm{~s}^{-1}$ on the Aquitaine shelf (Charria et al., 2013). This so-called residual circulation is controlled by wind, tides, and water density (Figure 1a) (Pingree and Le Cann, 1989).

\section{Hydrographical pattern of the continental shelf and surface productivity}

The hydrographical structure of the continental shelf of the BoB is highly seasonal (e.g. Castaing et al., 1999; Vincent and Kurc, 1969). One of the main features is the formation of a winter thermohaline front along the $\sim 100-\mathrm{m}$ isobath that lasts for several months (Castaing et al., 1999). This front results from the outflow of freshwaters mainly from the Loire and Gironde estuaries (Lazure and Jégou, 1998). The Loire and Gironde catchment areas are mostly characterized by a simple hydrological regime of oceanic-rainfall type (Joly et al., 2010), leading to maximum runoff during winter and early spring $\left(>1500 \mathrm{~m}^{3} \mathrm{~s}^{-1}\right)$ and minimum values during summer $\left(<300 \mathrm{~m}^{3} \mathrm{~s}^{-1}\right)$ (hydro.eaufrance.fr; Castaing and Allen, 1981). In response to high river runoff, temperature and salinity gradients in the $\mathrm{BoB}$ continental shelf are present from the inner shelf to the $100-\mathrm{m}$ isobath (from $\sim 10$ to $12^{\circ} \mathrm{C}$ and $\sim 30$ to 35.6 psu; Lazure et al., 2006; Lazure and Jégou, 1998). During summer, thermal stratification takes over with increasing temperatures (Puillat et al., 2004). Continental suspended matter derived from estuaries spreads out on the Armorican shelf by means of surface (i.e. turbide plume) and intermediate nepheloid layers (Castaing et al., 1979; Weber et al., 1991), which are transported by the northward residual circulation. Suspended particles may be trapped by the winter thermohaline front, and are deposited at $\sim 100-\mathrm{m}$ water depth as a mud belt (Lazure and Jégou, 1998). It is postulated that the position of this mud belt is linked to the long-term stable location of the thermohaline front that separates oceanic waters from coastal waters (Castaing et al., 1999). During summer, another front, the Ushant tidal front, takes place north of the study area in the Iroise Sea (Cadier et al., 2017). The dynamics of these fronts (i.e. strength of T-S gradient) 
Table I. AMS radiocarbon ages of core CBT-CSII.

\begin{tabular}{|c|c|c|c|c|c|c|}
\hline Lab. Number & $\begin{array}{l}\text { Depth } \\
(\mathrm{cm})\end{array}$ & Species & $\begin{array}{l}{ }^{14} \mathrm{C} \text { age } \\
(\mathrm{yr} \mathrm{BP})\end{array}$ & $\begin{array}{l}\text { Error } \\
(I \sigma)\end{array}$ & \multicolumn{2}{|c|}{$\begin{array}{l}\text { Calendar age }{ }^{\mathrm{a}} \text { range }(\mathrm{yr} \mathrm{BP}, 2 \sigma) \text { cor- } \\
\text { rected for reservoir age }{ }^{\mathrm{b}}\end{array}$} \\
\hline SacA4I576c & 0 & Turritella sp. & 720 & 30 & 305 & 476 \\
\hline SacA4I577c & 0 & Mixed benthic foraminifera & 1185 & 30 & 680 & 874 \\
\hline SacA4I578c & 19 & Mixed benthic foraminifera & 1315 & 30 & 787 & 982 \\
\hline SacA 32019c & 29 & Marine mollusk & 715 & 35 & 299 & 476 \\
\hline SacA 32020 & 50 & Turritella sp. & 645 & 30 & 263 & 424 \\
\hline Poz-7I200 & 79 & Turritella sp. & 820 & 30 & 423 & 539 \\
\hline SacA 32021 & 91 & Turritella sp. & 1340 & 30 & 825 & 1031 \\
\hline SacA38446 & 101 & Marine bivalve & 1505 & 30 & 993 & $121 \mid$ \\
\hline SacA39684 & 120 & Turritella sp. & 1765 & 30 & 1269 & 1444 \\
\hline SacA39683 & $|5|$ & Turritella sp. & 2180 & 35 & 1704 & 1927 \\
\hline SacA 32022 & 165 & Turritella sp. & 2600 & 30 & 2201 & 2449 \\
\hline SacA38447 & 170 & Turritella sp. & 2750 & 30 & 2384 & 2679 \\
\hline SacA 32023 & 187 & Turritella sp. & 3080 & 30 & 2778 & 3011 \\
\hline SacA 32024 & 203 & Marine dentaliidae & 3695 & 30 & 3558 & 3796 \\
\hline Poz-7I20I & 220 & Turritella sp. & 3875 & 35 & 3769 & 4048 \\
\hline SacA39682c & 220 & Turritella sp. & 3425 & 35 & 3222 & 3446 \\
\hline SacA3968I & 250 & Turritella sp. & 4940 & 35 & 5242 & 5448 \\
\hline SacA39680 & 278 & Turritella sp. & 5205 & 35 & 5508 & 5711 \\
\hline SacA 32025 & 315 & Turritella sp. & 5650 & 30 & 5981 & 6202 \\
\hline SacA38448 & 316 & Turritella sp. & 5630 & 30 & 5960 & 6183 \\
\hline SacA 32026 & 360 & Marine bivalve & 6200 & 30 & 6581 & 6793 \\
\hline SacA 32027 & 376 & Turritella sp. & 6415 & 30 & 6828 & 7086 \\
\hline SacA38449 & 385 & Turritella sp. & 6480 & 30 & 6925 & $7 \mid 48$ \\
\hline
\end{tabular}

${ }^{\text {a Corrected }}{ }^{14} \mathrm{C}$ ages were calibrated using the atmospheric calibration curve IntCall 3 (Reimer et al., 20I3).

${ }^{b}$ Reservoir correction inferred from Mangerud et al. (2006).

${ }^{c 14} \mathrm{C}$ age showing age inversion or incoherent results in comparison with the general tendency. SacA: code for ARTEMIS facilities; Poz: code for Poznan laboratory.

concentrate nutrient inputs, which in turn stimulate the seasonal production of phytoplankton in the northern BoB (e.g. Harlay et al., 2011; Pingree and Garcia-Soto, 2014; Sharples et al., 2009; Wollast and Chou, 2001).

\section{Material and methods}

\section{Coring method}

Piston core CBT-CS11 $\left(47^{\circ} 46.429 \mathrm{~N}, 4^{\circ} 25.308 \mathrm{~W} ; 73 \mathrm{~m}\right.$ water depth; $3.87 \mathrm{~m}$ long) was recovered about $4.5 \mathrm{~km}$ off the tip of south Brittany during the CABTEX cruise (June 2010, CALYPSO corer, R/V Pourquoi pas?, IFREMER; Dussud, 2010; Figure 1). A 6.26-m long core barrel was used with 1.68 tons of head weights to achieve a reasonable balance between the corer diameter (10 $\mathrm{cm})$ and the corer weight (2.205 tons). The corer was lowered to $1-\mathrm{m}$ distance from the sediment water interface before being released by a trigger. Before penetration, some of the supernatant water was sucked out and the corer over-penetrated the sediment (recovery ratio $=107 \%)$.

\section{Chronology}

A total of $23{ }^{14} \mathrm{C}$ dates, of which 21 were measured using French national ARTEMIS ${ }^{14} \mathrm{C}$ AMS facilities and two dates measured at Poznán Radiocarbon Laboratory, were obtained (Table 1). For dating, we used mostly the gastropod Turritella sp. When not found, other mollusks or mixed benthic foraminifera were used (Table 1). Absolute ${ }^{14} \mathrm{C}$ dates were corrected for the geographically nearest reservoir age of $324 \pm 24$ years (Mangerud et al., 2006). By using the Bchron package in R program (R Core Team, 2014), corrected AMS ${ }^{14} \mathrm{C}$ dates were converted to calendar ages (cal. ka BP) using the IntCal13 calibration curve (Reimer et al., 2013) and an age-depth model was computed based on $18{ }^{14} \mathrm{C}$ dates, five dates being considered as outliers from the main trend
(Figure 2). Most of the ${ }^{14} \mathrm{C}$ outliers are present in the upper $50 \mathrm{~cm}$ of the core. This might be the result of (a) physical disturbance during extraction, (b) bioturbation, and/or (c) the different nature of the dating material (Table 1). Therefore, the upper $50 \mathrm{~cm}(\sim$ the last $0.38 \mathrm{kyr}$ ) are not discussed in the following.

\section{$X R F$ and grain-size analyses}

The bulk intensity of elements $(\mathrm{Ca}, \mathrm{Sr}, \mathrm{Fe}, \mathrm{Ti}, \mathrm{Al}, \mathrm{Si}, \mathrm{Br}, \mathrm{Cl})$ was measured using an Avaatech XRF core scanner at 1-cm resolution at IFREMER (France). XRF data were measured with a $10 \mathrm{~s}$ count time, by setting the voltage to $10 \mathrm{kV}$ (no filter) and intensity to $600 \mathrm{~mA}$, except for $\mathrm{Sr}$ (voltage $30 \mathrm{kV}$ Pd thick filter; 1000 $\mathrm{mA}$ ). Because XRF scanning measures element intensities on a volumetric basis (i.e. sensitive to variations in grain size and density), XRF raw counts were normalized by applying the total number of counts (TNC) excluding Rh (x-ray tube) following the method of Bahr et al. (2014). To allow more robust statistical analyses, XRF ratios were converted to log-ratios (Tjallingii et al., 2007; Weltje and Tjallingii, 2008). It is generally accepted that $\mathrm{Ti}, \mathrm{Fe}, \mathrm{Al}$, and $\mathrm{Si}$ are related to the siliciclastic components of the sediment and vary with the terrigenous fraction (Jansen et al., 1998). Because sediments of 'La Grande Vasière' originate mainly from the Loire and Gironde Rivers and upper shelf environments, increased intensities of these elements are interpreted as increased supplies of siliciclastic material of continental origin (e.g. Chiessi et al., 2009; Haug et al., 2001; Nizou et al., 2011; Peterson et al., 2000). In marine sediments, the coarse sediment fraction is generally enriched in $\mathrm{Ti}$, while $\mathrm{Al}$ is mostly associated with fine-particle clay minerals, so that the ratio $\mathrm{Ti} / \mathrm{Al}$ changes can represent grain-size variations (e.g. Govin et al., 2012). In a siliciclastic margin, $\mathrm{Ca}$ and $\mathrm{Sr}$ often represent the carbonate content of the sediment (e.g. Govin et al., 2012; Rothwell et al., 2006), with Sr indicating the aragonite content (e.g. Bayon et al., 
2007). The biophilic halogen bromine ( $\mathrm{Br}$ ) is used as a tracer of organic matter in sediments, and the ratio $\mathrm{Br} / \mathrm{Cl}$ permits to isolate organic Br from salt-bounded $\mathrm{Br}$ (Ziegler et al., 2008).

$\mathrm{CaCO}_{3}$-free grain-size analyses were performed for 69 samples with a sample resolution of about $5 \mathrm{~cm}(\sim 100$-year resolution) using a laser diffraction particle size analyzer (Malvern ${ }^{\mathrm{TM}}$ Mastersizer 3000; LPG). Sediment decarbonatation was performed with $1 \mathrm{M}$ hydrochloric acid.

\section{Benthic foraminiferal assemblages}

Fifty-five sediment samples (on average every $7 \mathrm{~cm} ; \sim 130$ years resolution) were analyzed for their benthic foraminiferal content. Samples were dried and weighed to obtain dry weight. Samples were washed through $150 \mu \mathrm{m}$ and $63 \mu \mathrm{m}$ sieves. Although small sized and/or elongated adult species may compose a large part of the foraminiferal assemblage, the $63-150 \mu \mathrm{m}$ fraction was not considered in this study. However, the inspection of some samples from the small fraction revealed the presence of mainly juveniles of the species found in the larger fraction. Because of the high foraminiferal abundances, samples were split into subsamples (aliquots), using an Otto Microsplitter. More than $\sim 200$ specimens were picked out from a single aliquot under a binocular microscope, stored in separate Chapman slides (for each sample), and identified at a species level. In order to correct for the taphonomical loss of some agglutinated taxa because of their rapid disintegration, the few specimens of the only non-fossilizing species Eggerella scabra (Fontanier et al., 2003) were removed before calculating absolute and relative abundances. Diversity (Shannon index $H$ ) was calculated using the software PAST (PAleontological STatistics; Version 2.14; Hammer et al., 2001) following the formula, with $=$ the proportion of individuals belonging to the $i$ th species.

\section{Benthic foraminiferal oxygen and carbon stable isotopes}

Stable oxygen and carbon isotopes were measured on the epibenthic species Cibicides refulgens in 113 sediment samples $(\sim 3 \mathrm{~cm}$ spacing; 64 years resolution). For each sediment level, about 15 specimens of $C$. refulgens $(150-250 \mu \mathrm{m})$ were hand-picked, cleaned in a methanol ultrasonic bath for a few seconds, then roasted under vacuum at $380^{\circ} \mathrm{C}$ for $45 \mathrm{~min}$ to remove organic matter, prior to isotopic analyses. The $\delta^{18} \mathrm{O}$ and $\delta^{13} \mathrm{C}$ (\%oVPD) were measured at the PSO (IUEM, Brest) using the IRMS platform: a Delta V mass spectrometer coupled with a GasBench II preparation line for benthic species $(\sim 1$ test). The external reproducibility $(1 \sigma)$ of an internal standard calibrated with NBS19 is $\pm 0.05 \%$ and $0.15 \%$ for $\delta^{13} \mathrm{C}$ and $\delta^{18} \mathrm{O}$, respectively.

\section{Statistical and spectral analyses}

We performed a principal components analysis (PCA) and a Linear $r$ (Pearson) multiple correlation analysis on all our proxies using PAST software package (Hammer et al., 2001). Because our variables have different units, we used the correlation matrix (i.e. normalized variance-covariance) for PCA calculation (Hammer et al., 2001). As all proxies have different sampling resolution, data were resampled (i.e. interpolated between data points) at continuous and even spaced time-resolution according to the minimum time-resolution obtained by the proxy with the lowest resolution (i.e. $H=30$ years).

In order to explore the frequency in the temporal variability of selected parameters $\left(\delta^{18} \mathrm{O}, \delta^{13} \mathrm{C}\right.$, Shannon $H$, and XRF-Ti, $\mathrm{Br} / \mathrm{Cl}$, $\mathrm{Sr} / \mathrm{Ti}$ ), a Continuous Wavelet Transform (CWT) (Morlet wavelet) and REDFIT analyses were performed using the PAST software package (Hammer et al., 2001). Before spectral analyses, data

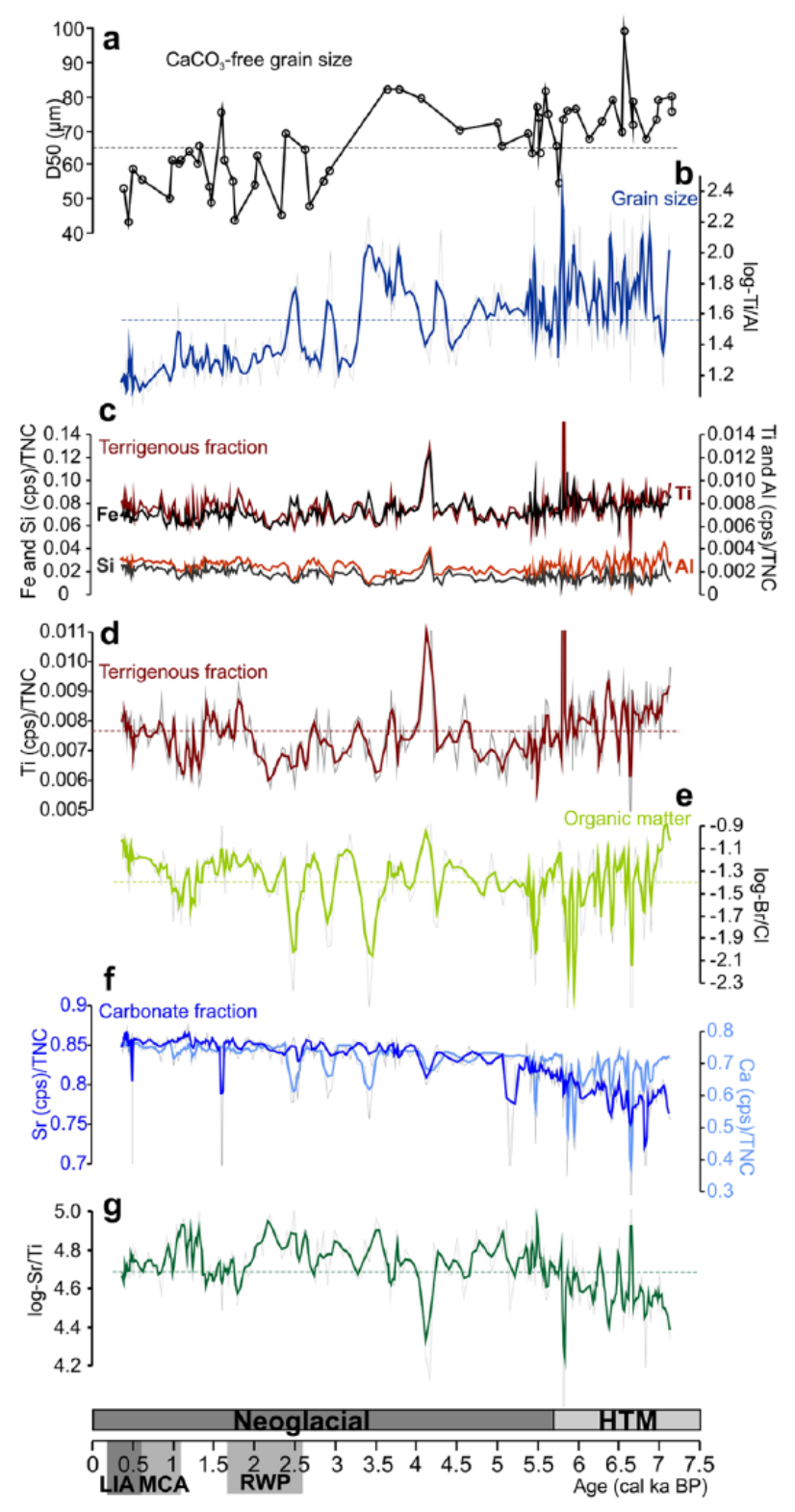

Figure 3. (a) $\mathrm{CaCO}_{3}$-free grain size $\mathrm{D} 50(\mu \mathrm{m})$; (b-g) XRF data. The tick lines in XRF data represent the 3-point moving average. The dashed horizontal lines are placed on the average value. LIA:'Little Ice Age'; MCA: Medieval Climate Anomaly; RWP: Roman Warm Period; HTM: Holocene Thermal Maximum.

were resampled (i.e. interpolated between data points) at continuous and even spaced time-resolution (according to the minimum time-resolution; $\mathrm{XRF}$ data $=5$ years, stable isotopes $=10$ years, and $H=30$ years).

\section{Results}

\section{Grain-size and XRF analyses}

Grain-size distribution shows a sharp drop in the median particle size (D50) changing from coarser $(\sim 75 \mu \mathrm{m})$ to finer sediments $(\sim 55 \mu \mathrm{m})$ between $\sim 3.5$ and 2.5 cal. ka BP (Figure 3a). XRF-Ti/ $\mathrm{Al}$ shows generally the same pattern with higher values before $\sim 3.5$ cal. ka BP (Figure 3b). XRF-Ti, which is positively correlated to $\mathrm{Fe}, \mathrm{Si}$, and $\mathrm{Al}$ (Figure $3 \mathrm{c}$ ), shows a great variability along the record oscillating between 0.006 and $0.011 \mathrm{cps} / \mathrm{TNC}$ (Figure $3 \mathrm{~d})$. $\mathrm{XRF}-\mathrm{Br} / \mathrm{Cl}$ values follow the same trend as $\mathrm{Ti}$ and oscillate between 0.10 and $0.40 \mathrm{cps} / \mathrm{TNC}$ (Figure 3e). XRF-Sr and $\mathrm{Ca}$ increase until $\sim 5 \mathrm{cal}$. $\mathrm{ka} \mathrm{BP}$ and remain generally stable after (Figure 3f). The ratio $\mathrm{Sr} / \mathrm{Ti}$ varies between 80 and $140 \mathrm{cps} / \mathrm{TNC}$ 
(Figure 3g) and follows a similar pattern as XRF-Sr and Ca but with amplified oscillation.

\section{Foraminiferal assemblages and stable isotopes}

Absolute foraminiferal abundances range between $~ 134$ and 631 ind $\mathrm{g}^{-1}$ of dry sediment, and generally increase along the record (Figure $4 b)$. Shannon diversity $(H)$ values show also an overall increase and range between 2.2 and 3 (Figure 4c). Percentages of the three major species $(>10 \%$ in at least one sample) are presented in Figure 4d and e. Rosalina globularis shows a general decrease from $35 \%$ in the early part of the record to less than $10 \%$ at $\sim 0.38$ cal. ka BP. Lobatula lobatula and C. refulgens show the opposite trend with increasing values over time from $\sim 10 \%$ to $20 \%$. The percentages of the minor species $(5-10 \%$ in at least one sample) are shown in Figure S1 (supplemental material, available online).

The stable oxygen isotope values of $C$. refulgens $\left(\delta^{18} \mathrm{O}_{C \text {. refulgens }}\right)$ show a great variability with a major change around $3.5-2.5 \mathrm{cal}$. ka BP (Figure 4f). Before $\sim 3.5-2.5$ cal. ka BP, $\delta^{18} \mathrm{O}_{\text {C. refulgens }}$ oscillates between $\sim-0.25 \%$ and $0.5 \%$, whereas after $\sim 3.5-2.5$ cal. ka $\mathrm{BP}$, values generally range between $0.4 \%$ and $1 \%$. The stable carbon isotope values of $C$. refulgens $\left(\delta^{13} C_{C \text {. refulgens }}\right)$ show also a great variability, oscillating between $\sim 1.1 \%$ and $1.5 \%$ (Figure 4g).

\section{Discussion}

\section{Evolution of benthic foraminiferal communities from middle to late Holocene}

The downcore foraminiferal composition is largely dominated by epiphytic/epibenthic calcareous species, mostly $R$. globularis, $L$. lobatula, and C. refulgens (Langer, 1988, 1993) (Figure 5). Coastal areas in Brittany are known for their abundant and diverse marine vegetation extending from supralittoral to circalittoral depths (e.g. Golléty et al., 2010; Hart, 2016; Stiger-Pouvreau et al., 2014). It is well known that these latter provide abundant niches worldwide for motile or (temporarily) fixed epiphytic foraminifera (Barras et al., 2014; Hart, 2016; Johnson and Scheibling, 1987; Langer, 1993). The steep inner to mid-shelf $(0-100 \mathrm{~m})$ bathymetric profile (Figure 1b) makes our study area close to the upper coastal habitats, explaining the large abundance of epiphytes and the difference with the nearby site $G$ located more distantly from the continent (Figure 1b; Duchemin et al., 2008). On the larger southern Brittany inner shelf (Bay of Etel; Figure 1b, vk16), a very similar Holocene fossil assemblage dominated by epiphytes was found in a core retrieved at $\sim 30 \mathrm{~m}$ water depth (Estournès et al., 2012).

Along the record, the evolution of the three main species follows two main long-term trends. $R$. globularis shows a general decreasing trend from middle to late Holocene (Figure 4d), whereas the opposite is observed for L. lobatula and C. refulgens (Figure $4 \mathrm{~d}$ and e). In the $\mathrm{BoB}, R$. globularis is commonly found in phytal environments in the vicinity of estuaries (Martínez-García et al., 2013; Pascual et al., 2008). R. globularis is a temporary attached species (e.g. to algae, marine grasses) secreting an organic glue to fix its test to the substrate, but it can free itself when searching for food or during sexual reproduction (Delaca and Lipps, 1972). Rosalina is one of the few genera that calcifies a special float chamber in a temporary planktonic phase, immediately before and during gametogenesis (Banner et al., 1985; Sliter, 1965). As such, this species can be easily transported by currents. This might explain the strong positive correlation between $R$. globularis and the D50 (i.e. strong hydrodynamics) especially before $\sim 4.5-5 \mathrm{ka}$ BP characterized by lower RSL stand (Figure 4a). However, with relative abundances reaching 30-40\%, the transport alone is hardly conceivable. According to Sliter (1965)

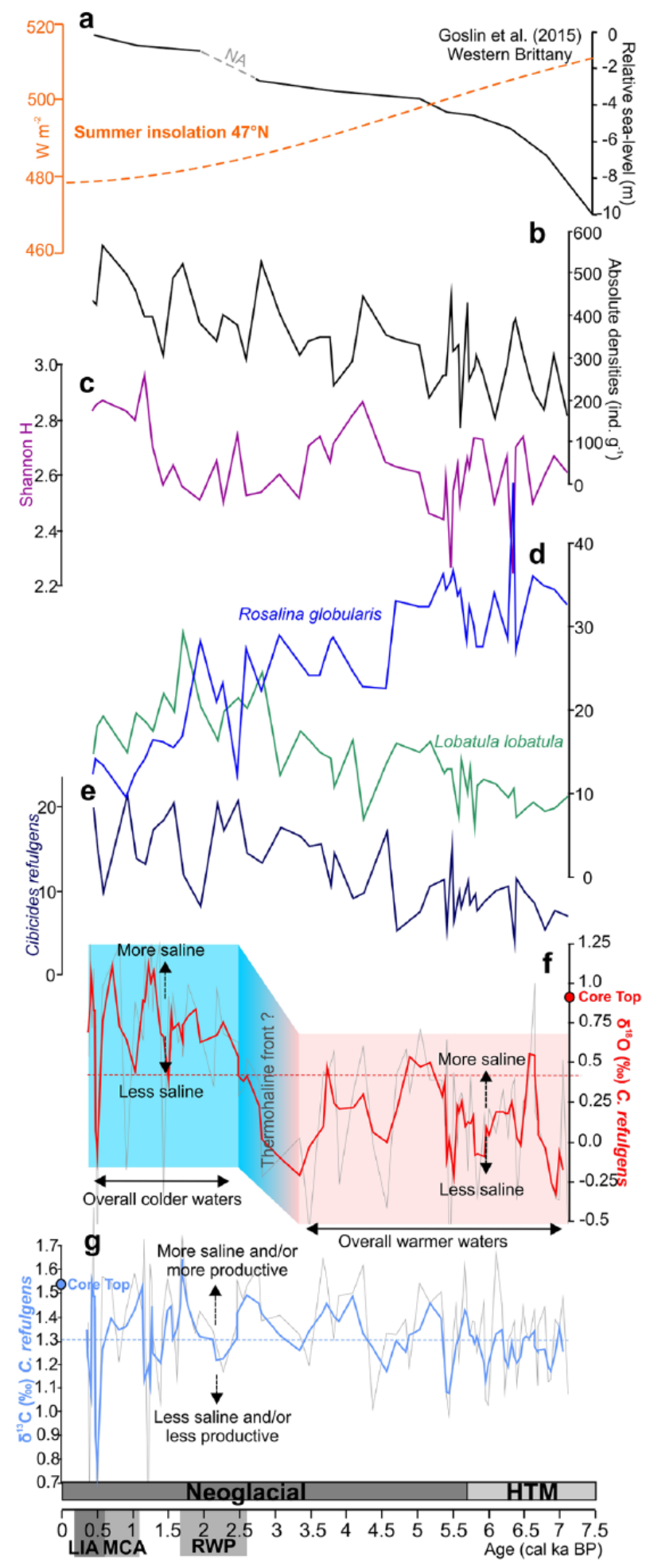

Figure 4. (a) Summer insolation at $47^{\circ} \mathrm{N}$ and a simplified Holocene reconstruction of sea level in Brittany (Goslin et al., 20I5); (b) total benthic absolute densities (ind $\mathrm{g}^{-1}$ ); (c) diversity index (Shannon $H)$; $(\mathrm{d}-\mathrm{e})$ relative abundances $(\%)$ of the three dominant benthic foraminiferal species; $(f-g)$ oxygen and carbon stable isotopes measured on the benthic species Cibicides refulgens. The tick curves represent the 3-point moving average. The dashed horizontal lines are placed on the average values. LIA: 'Little Ice Age'; MCA: Medieval Climate Anomaly; RWP: Roman Warm Period; HTM: Holocene Thermal Maximum.

and Saraswat et al. (2011), sexual reproduction and thus also the floating chambers only occur at temperatures above $18^{\circ} \mathrm{C}$. Therefore, the general cooling trend in summer SSTs recorded from middle to late Holocene in the $\mathrm{BoB}$ (from $\sim 22$ to $<18^{\circ} \mathrm{C}$; 
a

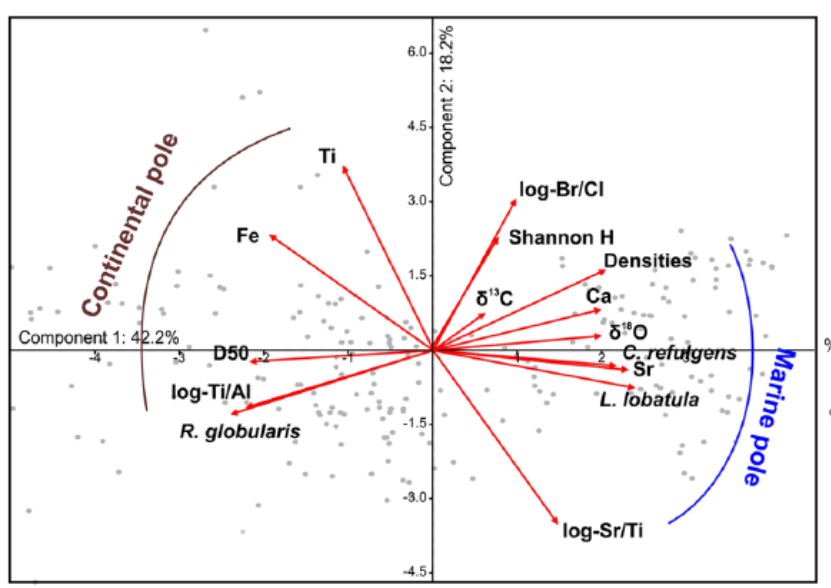

b

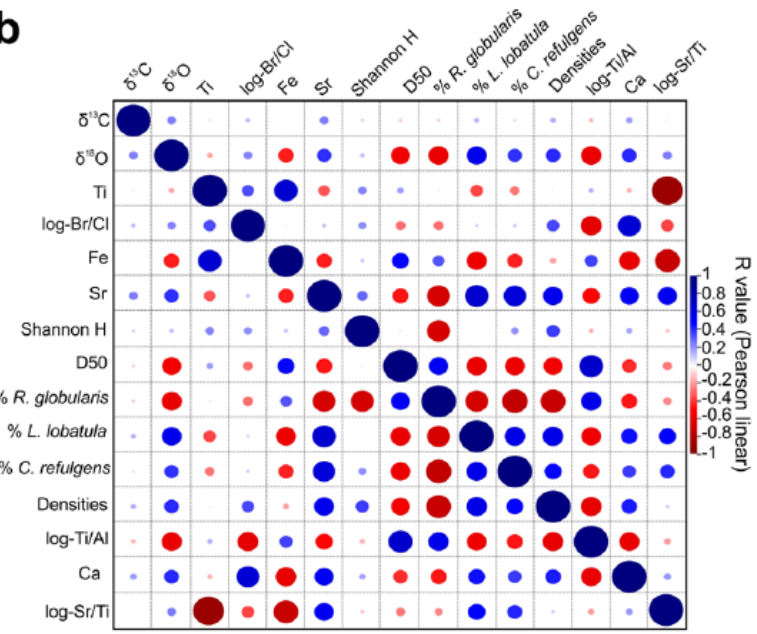

Figure 5. Statistical analyses: (a) PCA analysis based on correlation between proxies; (b) graph representing the results of the linear multiple correlations between proxies. Colors refer to Pearson correlation $r$, with blue/red referring to positive/negative correlation. The size and the color intensity of the round symbols are proportional to the strength of the correlation. Non-significant correlations $(p>0.05)$ are not represented.

Zumaque et al., 2017), which is coherent with the decreasing trend in summer insolation (Figure 4a), might also explain the long-term decreasing trend of $R$. globularis (Figure 4d). In addition to temperature, the progressive deepening of the study site in response to RSL rise $(\sim 7 \pm 1 \mathrm{~m}$ since $7 \mathrm{ka}$; Goslin et al., 2015; Figure 4a) might have moved shoreward the habitat of $R$. globularis. L. lobatula and C. refulgens habitats are not restricted to upper shelf environments but can extend to bathyal depths (García-Gallardo et al., 2017; Hayward et al., 2010). When attached on plants, $L$. lobatula and $C$. refulgens are permanently sessile (Langer, 1993; Langer and Gehring, 1993). By being able to inhabit greater water depths (Hayward et al., 2010), L. lobatula and $C$. refulgens might have adapted more easily to the deeper habitat. In the end, it is very likely that this long-term ecological benthic foraminiferal pattern results from the overlay of these environmental parameters.

On a shorter millennial time-scale, high density and diversity of benthic foraminiferal faunas are coherent with periods of (a) fine sedimentation (i.e. low D50 and log-Ti/Al) relatively rich in organic matter (i.e. high $\log -\mathrm{Br} / \mathrm{Cl}$ ) and carbonate content (i.e. high $\mathrm{Ca}$ and $\mathrm{Sr}$ ) and (b) high $\delta^{18} \mathrm{O}$ and $\delta^{13} \mathrm{C}$ values that we interpret in the following as more saline and potentially more productive waters (Figures 4 and 5). These features are coherent with our current knowledge of the ecological requirements of benthic foraminifera in the BoB. Indeed, fine-grained sediments, high labile organic content, low hydrodynamics, and normal open ocean salinity values $(\sim 35)$ have all been shown to influence positively the density and diversity of benthic foraminifera (e.g. Fontanier et al., 2002; Jorissen et al., 1995; Mojtahid et al., 2009; Saraswat et al., 2015).

\section{Hydrological features implied from the foraminiferal isotopic signature}

The core top values of $\delta^{13} \mathrm{C}$ and $\delta^{18} \mathrm{O}$ of the epifaunal C. refulgens $(\sim 1.6 \%$ and $\sim 0.9 \%$, respectively; Figure 6$)$ are in agreement with the modern isotopic signature of surface waters $(0-100 \mathrm{~m})$ in the BoB (Fontanier et al., 2006), implying that this species calcifies in equilibrium with bottom waters. The $\delta^{13} \mathrm{C}$ of Cibicides species reflects the $\delta^{13} \mathrm{C}$ of dissolved inorganic carbon (DIC) (e.g. Duplessy et al., 1984; Schmittner et al., 2017). The $\delta^{18} \mathrm{O}$ of foraminiferal calcite reflects the temperature of calcification and the $\delta^{18} \mathrm{O}$ of the seawater in which it calcifies, which in turn depends on salinity (e.g. Ravelo and Hillaire-Marcel, 1999). It is therefore impossible to deconvolve temperature and salinity effects without an additional independent temperature/salinity-proxy. On one hand, the significant positive correlation between depleted foraminiferal $\delta^{18} \mathrm{O}$ values and terrestrial source proxies (XRF-Ti, Fe) (Figure 5) may indicate a link to continental/freshwater input, and thus to a possible dominant salinity control over the $\delta^{18} \mathrm{O}$ signature during periods of high river runoff. That said, the $\delta^{18} \mathrm{O}-\mathrm{Fe} / \mathrm{Ti}$ link is partially biased by the difficulty to differentiate between the continental sources of $\mathrm{Ti}$ and $\mathrm{Fe}$ in our sediments (i.e. direct river discharges or upper shelf erosion during storm events). On the other hand, continental waters are depleted in both $\delta^{18} \mathrm{O}$ (water) and $\delta^{13} \mathrm{C}$ (DIC) in opposite to marine waters. Duplessy (1972) found that $\delta^{18} \mathrm{O}$ (water) and $\delta^{13} \mathrm{C}$ (DIC) in the Loire estuary are highly quasi-linearly correlated over the entire mixing range of marine and freshwater end members. Interestingly, the Loire freshwater has a very negative $\delta^{13} \mathrm{C}(\sim-10 \%)$ because most of the DIC stems from the remineralization of organic carbon in ground waters. Therefore, any variation in freshwater input to the core site, even though relatively distant from the Loire river mouth, should therefore leave an imprint in the $\delta^{13} \mathrm{C}$ of epibenthic foraminifera. In our record, $\delta^{18} \mathrm{O}$ and $\delta^{13} \mathrm{C}$ show a significant, but weak $(r=0.25$; Figure 5$)$ positive correlation, which might corroborate a partial control of continental freshwater input over the foraminiferal isotopic signature. That said, the weak $\delta^{18} \mathrm{O}$ and $\delta^{13} \mathrm{C}$ correlation implies that other factors are involved, especially for $\delta^{13} \mathrm{C}$ that is affected by local primary production (enriched in ${ }^{13} \mathrm{C}$ ). Therefore, periods of relatively high $\delta^{13} \mathrm{C}$ can indicate a more productive water column, perhaps triggered by fluvial nutrient inputs.

The major deviation recorded in the $\delta^{18} \mathrm{O}$ from $\sim 3.5$ to 2.5 cal. ka BP is not recorded in the $\delta^{13} \mathrm{C}$ (Figure $4 \mathrm{f}$ and $\mathrm{g}$ ). This may imply an additional temperature control resulting probably from a major change in the hydrological configuration of the study area and probably of the BoB. At a regional scale, the 3.5-2.5 cal. ka BP time period coincides with the maximum of the Holocene transgression (e.g. Goslin et al., 2015; Ters et al., 1968) (Figure 4a). During periods of sea level high stand, freshwater coastal wetlands were inundated and coastal bays and rias were flooded, acting as sinks for fluviatile sediments (e.g. Morris and Mitchell, 2013; van Maren et al., 2016). Once the downstream valleys filled and the rivers channelized, suspended sediments and freshwaters were not anymore trapped by these coastal systems and therefore exported offshore leading to a significant reduction in coastal accommodation spaces (Clavé et al., 2001; Durand et al., 2016; 
Spencer et al., 1998; Traini et al., 2015). The resulting overall increase in freshwater load into the BoB certainly affected the hydrographical structure on the continental shelf leading eventually to the establishment of the modern winter thermohaline front located around $100 \mathrm{~m}$ water depth as previously suggested by Castaing et al. (1999) and Dubrulle et al. (2007). This front is the eastern boundary of warm and salty oceanic waters and the western boundary of colder and less salty shallow coastal waters (Castaing et al., 1999). According to Castaing et al. (1999), continental waters arriving at our site are materialized by major river plumes carrying organic-rich fine-grained sediments. In our core, this can be reflected by the finer grain-size distribution recorded after $\sim 3.5-2.5 \mathrm{cal}$. ka BP (Figure 3a). Superimposed to this purely hydrological scenario, we cannot discard other possible factors such as climate forcing and early human impact triggering and/or amplifying the observed change. Indeed, the time period from $\sim 3.5$ to 2.5 cal. ka BP records a major storm event reported in northern Europe (Sorrel et al., 2012) and western Brittany (Van Vliet-Lanoë et al., 2014), and corresponds with increasing rainfall over the Loire and Gironde catchment areas (Naughton et al., 2007). Furthermore, several palynological studies have shown that human activity (e.g. forest clearing, livestock, crop farming) was already present at the time in the Loire catchment area (e.g. Visset et al., 2002), but it is only since $\sim 2.0$ cal. kyr BP that this activity impacted partly the terrigenous supply through soil erosion (Naughton et al., 2007).

After detrending the isotopic signal from the possible thermohaline front effect (Figure $6 \mathrm{~b}$ ), the $\delta^{18} \mathrm{O}$ variability of our oxygen isotopic signal seems also to be consistent with open oceanic North Atlantic records, at least for some specific periods (6.6, 5.9, 4.6, 4, 3.3, 2.5 cal. ka BP; Figure 6). This may further imply a probable link to larger scale hydrological patterns, such as those identified in the North Atlantic for the AMOC (Wanner et al., 2008). For example, at the Meriadzek Terrace (site MD95-2002 at $\sim 300 \mathrm{~km}$ west from CBT-CS11; Figure 1), dinocyst assemblages and stable isotope data reveal alternating low and high salinity episodes since $11 \mathrm{ka} \mathrm{BP}$ (Figure 6c) (Zumaque et al., 2017). The low salinity episodes match dense sea-ice cover in the Labrador Sea (Solignac et al., 2004). Although the time-resolution is lower than in our study, we observe a general coherency between $\delta^{18} \mathrm{O}_{C \text {. refulgens }}$ and the reconstructed sea surface salinities produced by Zumaque et al. (2017), except around 5.1 and after $\sim 2$ cal. ka BP (Figure 6). Interestingly, our low salinity events seem to match the cooling pulses defined by Bond et al. (1997) and characterized by episodes of increasing ice-rafted debris in the northern latitudes (Figure 6a). Furthermore, the overall good consistency between the heavier/ lighter values of benthic $\delta^{18} \mathrm{O}$ signal (i.e. high/low salinity) at our site with periods of weak/strong SPG circulation (Thornalley et al., 2009) (Figure 6d) seems to corroborate the previous hypothesis. Indeed, strong SPG circulation results in a more east-westoriented gyre, leading to more freshwater contribution (mostly from Greenland ice meltwaters) to the Atlantic inflow and a consequent weakening of the AMOC (Hátún et al., 2005). The opposite is observed when weak SPG results in a more north-south-oriented gyre (Staines-Urías et al., 2013; Thornalley et al., 2009). Periods of intensified AMOC lead to an active northward transport of warm and salty subtropical waters, which is also consistent with SST records from western subtropical coasts of Africa (deMenocal et al., 2000) (Figure 6f). Such connection between the BoB and the Labrador Sea has been suggested by Mary et al. (2017) at sites ProsecanKS10b and PP10-07 (Figure 1). Thus, we can also hypothesize that our isotopic signal might be also modulated by open water salinity changes (driven by AMOC variability).

\section{Millennial-scale variability and controlling factors}

Our data show a considerable high frequency variability superimposed on longer term trends. From middle to late Holocene,

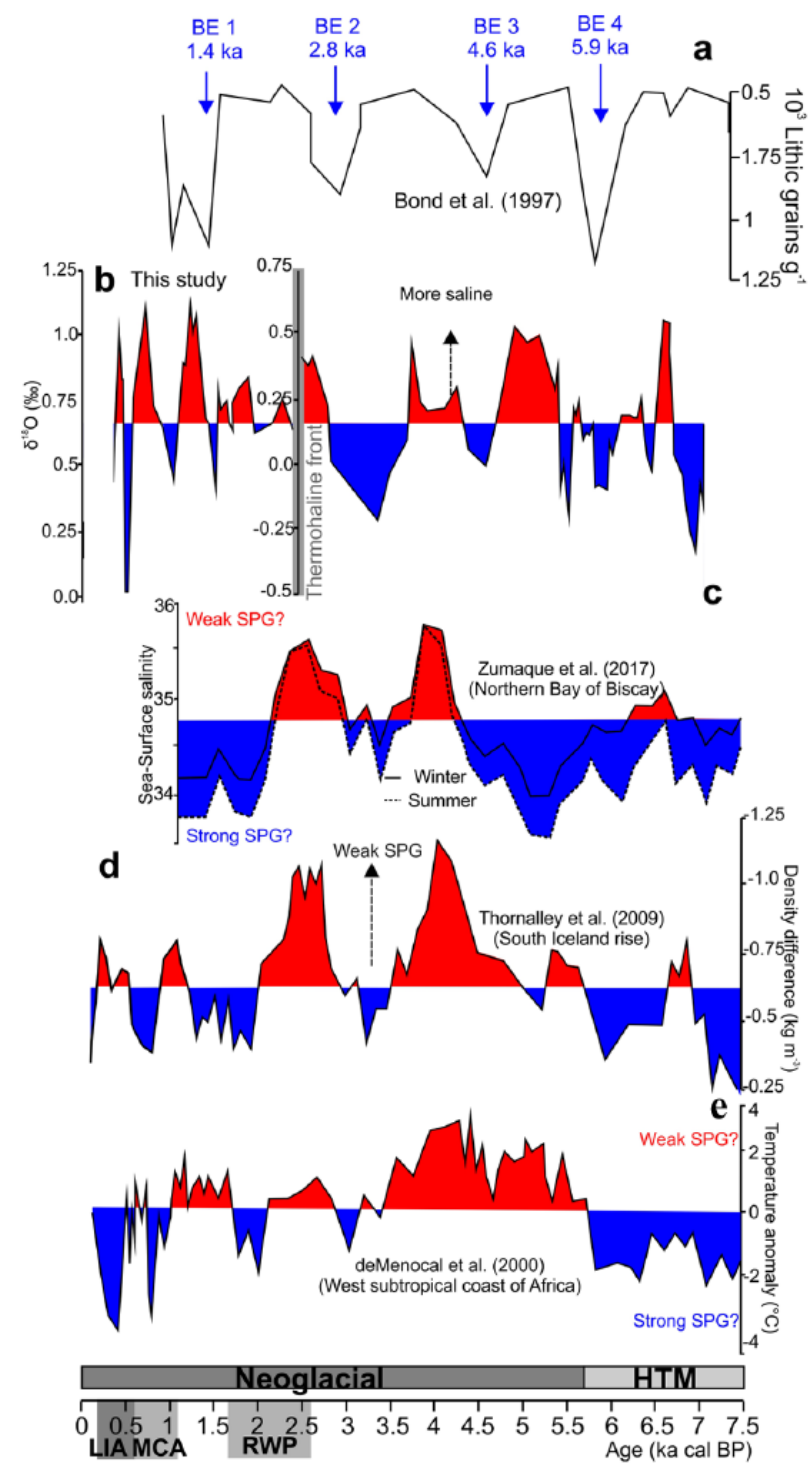

Figure 6. Comparison to intervals/episodes defined from other studies at the regional to global scale: (a) concentration of lithic grains from the work of Bond et al. (1997); (b) 3-point average curve of benthic foraminiferal $\delta^{18} \mathrm{O}$ at our study site. The pre and post $\sim 2.5$ cal. ka BP periods have separated scales in order to ignore the potential thermohaline front; (c) winter and summer sea surface salinities estimated from dinocysts in core MD95-2002 (Zumaque et al., 2017); (d) 3-point average density difference proxy from core Rapid-I2-IK (Thornalley et al., 2009) calculated using derived $\mathrm{Mg} / \mathrm{Ca}$ and $\delta^{18} \mathrm{O}$ temperatures and salinities of Globigerina bulloides and Globorotalia inflata; (e) sea surface temperature anomalies calculated using transfer function on planktic foraminiferal assemblages in core ODP Hole $658 \mathrm{C}$ (deMenocal et al., 2000). The interpretative horizontal line separating red and blue colored areas are placed around the average between maximum and minimum values of the total variability.

spectral analyses carried out on XRF-Ti, XRF-Br/Cl, XRF-Sr/Ti, $\delta^{18} \mathrm{O}$, and $\delta^{13} \mathrm{C}$ signals revealed a statistically significant $1250-$ year frequency peak (Figure 7), but not a pervasive 1500-year cycle as reported in several studies from the North Atlantic (e.g. Bond et al., 1997; Debret et al., 2007; Thornalley et al., 2009; Wanner et al., 2008). The only exception is for Shannon index presenting a 1360-1760-year peak, which is probably because of the lower sampling resolution (Figure 7). Although Bond et al. (1997) concluded that pacings of the Holocene and glacial events are the same statistically, and together constitute a cyclic signal centered on $1470 \pm 532$ years, they specified that the mean pacing for Holocene events is $1374 \pm 502$ years. A similar periodicity of 1300 years was recorded in sediments of the Loire River 


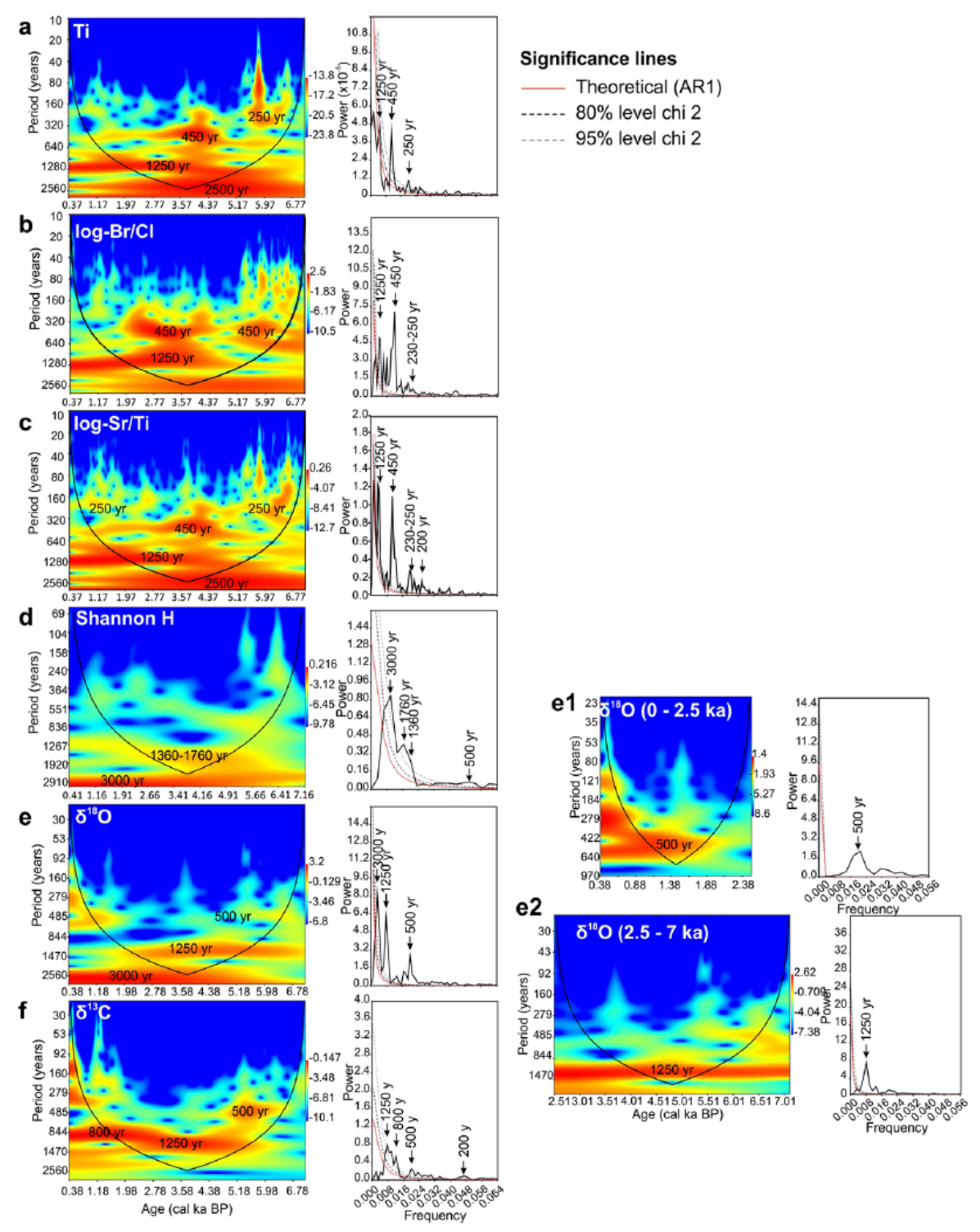

Figure 7. Continuous Wavelet Transform (CWT) analyses (periodicities) and REDFIT analyses (power spectra) performed on (a) log-Ti, (b) log- $\mathrm{Br} / \mathrm{Cl}$, (c) log-Sr/Ti, (d) Shannon $\mathrm{H}$, (e, el, e2) $\delta^{18} \mathrm{O}$, and (f) $\delta^{13} \mathrm{C}$. For CWT, the cone of influence is plotted to show the region where boundary effects are present and the signal power (squared correlation strength with the scaled mother wavelet) is shown in color scale.

mouth (core KV14-bis; Figure 1a), although the significance of the frequency peak is not very robust since this core covers only the past 2600 years (Durand et al., in press). Also, a periodicity of 1300 years has been reported by Pisias et al. (1973) and (Moros et al., 2006) in sediment cores from the North Atlantic. Debret et al. (2009) argued that frequencies with periods of 1250/1350 years are more common in the Southern ocean (e.g. Delmonte et al., 2002) whereas the 1500/1600-year cycles are more frequent in the North Atlantic. Debret et al. (2009) and Soon et al. (2014) conclude that the periodicities from 1250 to 1600 years most likely reflect an internal forcing which is distinct from the fundamental solar modes at 2300-year (Hallstattzeit), 1000-year (Eddy), and 500-year (unnamed) periodicities. Spectral analysis of the Holocene density stratification record of Thornalley et al. (2009) from the South Iceland rise (Figure 6d) shows one broad peak centered at 1500 years. These authors argued that the heat transport toward the northern latitudes has undergone largeamplitude millennial variability modulated by SPG dynamics. In addition to oceanic processes, a similar millennial cyclicity is also documented in continental records (Denton and Karlén, 1973; Solomina et al., 2015), and periods of intensified storminess in northern Europe (Sorrel et al., 2012), which strongly suggests an ocean-atmosphere connection. In our study site, NAO-like processes can represent a probable climatic forcing controlling both precipitations over the main French rivers' catchment areas and therefore river runoff into the $\mathrm{BoB}$, and wind stress that modulates SPG dynamics over the North Atlantic. Although the Holocene millennial climate variability is difficult to reconcile with the meteorological NAO dynamics that favors annual to decadal time-scale variations (Hurrell et al., 2003), North Atlantic Holocene records and climate model simulations show that millennialscale hydrographic changes exhibit spatial patterns that reproduce fairly well the seesaw associated with the NAO (Jessen et al., 2011; Rimbu et al., 2003; Schmidt et al., 2004; Schulz et al., 2007; Thornalley et al., 2009). In addition to the NAO, the AMO (Mann et al., 2009) has been identified as a coherent pattern of oceanic oscillatory changes in North Atlantic SSTs at multidecadal time-scales, displaying a spatial pattern resembling that of the atmospheric NAO mechanism (Mann et al., 2009; Sutton and Hodson, 2005). This link has been hypothesized in previous studies from the BoB (e.g. Durand et al., in press; Garcia et al., 2013; Mary et al., 2017; Mojtahid et al., 2013; Zumaque et al., 2017). However, every region and every proxy record has a different sensitivity to these mechanisms that are further modulated by local changes in the sedimentation (e.g. sedimentation rate, diagenesis, etc.). 
There appear to be other significant higher frequency oscillations corresponding to multi-century periods of which the 450/500 years is a recurrent peak (Figure 7). This periodicity was also recorded in core KV14-bis (Figure 1a) in front of the Loire estuary and a strong link to solar forcing was hypothesized (Durand et al., in press). In fact, a 500-year Holocene cycle in solar activity was inferred from variations of global atmospheric ${ }^{14} \mathrm{CO}_{2}$ production (Stuiver et al., 1997). It has been strongly suggested that the $\sim 500$-year periodic solar irradiance plays a key role in cyclic oceanic and atmospheric change including NAO-like processes.

\section{Conclusion}

We present a paleoenvironmental history for the northern BoB for the past $7 \mathrm{kyr}$. The benthic foraminiferal fauna is dominated by three epiphytic/epibenthic species (R. globularis, L. lobatula, and $C$. refulgens). Through the record, absolute and relative densities of the three species display a long-term mid- to late-Holocene pattern with $R$. globularis showing a general decrease whereas the opposite is observed for $L$. lobatula and C. refulgens. The pattern of $R$. globularis can be explained by the overall SST cooling and/ or the progressive deepening of the water column due to RSL rise. By being able to inhabit greater water depths, L. lobatula and $C$. refulgens might have adapted to deeper habitats with time. In addition to these long-term benthic foraminiferal patterns, a millennial-scale variability is recorded by all our proxies. This variability seems to be closely linked with changes in precipitations over the catchment areas of the main French rivers and/or with AMOC variability, itself modulated by SPG dynamics. We further suggest a NAO-like process controlling both humidity over the main rivers' catchments areas and SPG dynamics through wind stress. Solar forcing seems to be superimposed to this millennial variability.

Foraminiferal $\delta^{18} \mathrm{O}$ and grain-size analyses show a major shift toward heavier isotopic values and finer sedimentation around 3.5-2.5 cal. ka BP. We hypothesize a link with the near-stabilization of sea-level rise since $\sim 3.5-2.5 \mathrm{cal}$. ka BP, resulting in the reduction of estuarine accommodation spaces and the channelization of the main rivers outflow. This likely caused extended freshwater and suspended sediment input into coastal waters of the $\mathrm{BoB}$, triggering therefore the formation of the present-day winter 100 -m isobath thermohaline front. This time period also coincides with increased storminess in northern Europe and Brittany, and increased rainfall on the Loire River catchment area. These factors may have triggered and/or amplified the observed change by affecting the hydrology of the BoB.

\section{Funding}

This study was supported by the French CNRS INSU and is a contribution to the 2013-2014 LEFE-IMAGO project 'HCOG2' ('Forçages climatiques Holocène et répercussions Côtières et Océaniques dans le Golfe de Gascogne'; coord. A. Penaud) and by the Nantes Saint-Nazaire seaport (project 'DETAiLH': DETermination de l'état pré-Anthropique de l'estuaire de la Loire et évolution Historique de son fonctionnement, coord. M. Mojtahid). ${ }^{14} \mathrm{C}$ dates were obtained, thanks to French national ARTEMIS 14C AMS facilities. We would like to thank Oanez Lebeau (IUEM, Brest) from the 'Pôle Spectrométrie Océan' (IUEM, CNRS, IFREMER) for her help with isotope analyses. We also thank IFREMER for core acquisition and laboratory facilities. This study represents a contribution to the French ANR project HAMOC. This work was also supported by the 'Laboratoire d'Excellence' LabexMER (ANR-10-LABX-19) and co-funded by a grant from the French government under the program 'Investissements d'Avenir'. Raw data are available as online supplemental material or by contacting the first author (e-mail: meryem.mojtahid@univ-angers.fr).

\section{Supplemental Material}

Supplemental material for this article is available online.

\section{References}

Aigner T (1985) Storm Depositional Systems: Dynamic Stratigraphy in Modern and Ancient Shallow-Marine Sequences. Berlin and Heidelberg: Springer-Verlag, p. 174.

Andreieff P, Bouysse P, Chateauneuf J-JL et al. (1971) La couverture sédimentaire meuble du plateau continental externe de la Bretagne méridionale (Nord du golfe de Gascogne). Cahiers Océanographiques, Xxiiième Année 4: 343-381.

Bahr A, Jiménez-Espejo FJ, Kolasinac N et al. (2014) Deciphering bottom current velocity and paleoclimate signals from contourite deposits in the Gulf of Cádiz during the last 140 kyr: An inorganic geochemical approach. Geochemistry, Geophysics, Geosystems 15(8): 3145-3160.

Banner FT, Pereira CPG and Desai D (1985) 'Tretomphaloid' float chambers in the Discorbidae and Cymbaloporidae. Journal of Foraminiferal Research 15(3): 159-174.

Barras C, Jorissen FJ, Labrune C et al. (2014) Live benthic foraminiferal faunas from the French Mediterranean Coast: Towards a new biotic index of environmental quality. Ecological Indicators 36: 719-743.

Bartels-Jónsdóttir HB, Knudsen KL, Abrantes F et al. (2006) Climate variability during the last 2000 years in the Tagus Prodelta, western Iberian Margin: Benthic foraminifera and stable isotopes. Marine Micropaleontology 59(2): 83-103.

Bayon G, Pierre C, Etoubleau J et al. (2007) $\mathrm{Sr} / \mathrm{Ca}$ and $\mathrm{Mg} / \mathrm{Ca}$ ratios in Niger Delta sediments: Implications for authigenic carbonate genesis in cold seep environments. Marine Geology 241(1): 93-109.

Boé $\mathrm{J}$ and Habets F (2014) Multi-decadal river flow variations in France. Hydrology and Earth System Sciences 18(2): 691-708.

Bond G, Showers W, Cheseby M et al. (1997) A pervasive millennial-scale cycle in North Atlantic Holocene and glacial climates. Science 278(5341): 1257-1266.

Born A and Stocker TF (2014) Two stable Equilibria of the Atlantic Subpolar Gyre. Journal of Physical Oceanography 44(1): 246-264.

Bourillet J-F, Jouanneau JM, Macher C et al. (2006a) La Grande Vasière mid-shelf mud belt: Holocene sedimentary structure, natural and anthropogenic impacts. In: Proceedings of the $X$ International Symposium on Oceanography of the Bay of Biscay, Vigo, 19-21 April. Available at: http://archimer.ifremer. fr/doc/00000/6243/.

Bourillet J-F, Zaragosi S and Mulder T (2006b) The French Atlantic margin and deep-sea submarine systems. Geo-Marine Letters 26(6): 311-315.

Brocheray S, Cremer M, Zaragosi S et al. (2014) 2000 years of frequent turbidite activity in the Capbreton Canyon (Bay of Biscay). Gmarineology 347: 136-152.

Cadier M, Gorgues T, Sourisseau M et al. (2017) Assessing spatial and temporal variability of phytoplankton communities' composition in the Iroise Sea ecosystem (Brittany, France): A 3D modeling approach. Part 1: Biophysical control over plankton functional types succession and distribution. Journal of Marine Systems 165: 47-68.

Castaing P, Allen G, Houdart M et al. (1979) Étude par télédétection de la dispersion en mer des eaux estuariennes issues de la Gironde et du Pertuis de Maumusson. Oceanologica Acta 2(4): 459-468.

Castaing P and Allen GP (1981) Mechanisms controlling seaward escape of suspended sediment from the Gironde: A macrotidal estuary in France. Marine Geology 40(1): 101-118.

Castaing P and Jouanneau JM (1987) Les apports sédimentaires actuels d'origine continentale aux océans. Bulletin-Institut de Geologie du Bassin d'Aquitaine 41: 53-65. 
Castaing P, Froidefond JM, Lazure P et al. (1999) Relationship between hydrology and seasonal distribution of suspended sediments on the continental shelf of the Bay of Biscay. Deep Sea Research Part II: Topical Studies in Oceanography 46(10): 1979-2001.

Charria G, Lazure P, Le Cann B et al. (2013) Surface layer circulation derived from Lagrangian drifters in the Bay of Biscay. Journal of Marine Systems 109-110: S60-S76.

Chevalier L, Laignel B, Massei N et al. (2014) Hydrological variability of major French rivers over recent decades, assessed from gauging station and GRACE observations. Hydrological Sciences Journal 59(10): 1844-1855.

Chiessi CM, Mulitza S, Pätzold J et al. (2009) Possible impact of the Atlantic multidecadal oscillation on the South American summer monsoon. Geophysical Research Letters 36(21): L21707.

Clark PU, Pisias NG, Stocker TF et al. (2002) The role of the thermohaline circulation in abrupt climate change. Nature 415(6874): 863-869.

Clavé B, Massé L, Carbonel P et al. (2001) Holocene coastal changes and infilling of the La Perroche marsh (French Atlantic coast). Oceanologica Acta 24(4): 377-389.

Costoya X, Fernández-Nóvoa D, deCastro M et al. (2017) Loire and Gironde turbid plumes: Characterization and influence on thermohaline properties. Journal of Sea Research. Available at: http://www.sciencedirect.com/science/article/pii/ S1385110116302398.

Debret M, Bout-Roumazeilles V, Grousset F et al. (2007) The origin of the 1500-year climate cycles in Holocene NorthAtlantic records. Climate of the Past 3(4): 569-575.

Debret M, Sebag D, Crosta X et al. (2009) Evidence from wavelet analysis for a mid-Holocene transition in global climate forcing. Quaternary Science Reviews 28(25): 2675-2688.

Delaca TE and Lipps JH (1972) The mechanism and adaptive significance of attachment and substrate pitting in the foraminiferan Rosalina globularis d' Orbigny. Journal of Foraminiferal Research 2(2): 68-72.

Delmonte B, Petit JR and Maggi V (2002) LGM-Holocene changes and Holocene millennial-scale oscillations of dust particles in the EPICA Dome C ice core, East Antarctica. Annals of Glaciology 35: 306-312.

deMenocal P, Ortiz J, Guilderson T et al. (2000) Coherent highand low-latitude climate variability during the Holocene warm period. Science 288(5474): 2198-2202.

Denton GH and Karlén W (1973) Holocene climatic variationsTheir pattern and possible cause. Quaternary Research 3(2): 155-205.

Dickson R and Hughes D (1981) Satellite evidence of mesoscale eddy activity over the Biscay abyssal-plain. Oceanologica Acta 4(1): 43-46.

Dubrulle C, Jouanneau JM, Lesueur P et al. (2007) Nature and rates of fine-sedimentation on a mid-shelf: 'La Grande Vasière' (Bay of Biscay, France). Continental Shelf Research 27(16): 2099-2115.

Duchemin G, Jorissen FJ, Le Loc'h F, et al. (2008) Seasonal variability of living benthic foraminifera from the outer continental shelf of the Bay of Biscay. Journal of Sea Research 59(4): 297-319.

Duplessy J-C (1972) La géochimie des isotopes stables du carbone dans la mer. Paris: Université de Paris VI. Available at: https://catalog.hathitrust.org/Record/007267394.

Duplessy J-C, Shackleton NJ, Matthews RK et al. (1984) 13C Record of benthic foraminifera in the last interglacial ocean: Implications for the carbon cycle and the global deep water circulation. Quaternary Research 21(2): 225-243.

Durand M, Mojtahid M, Maillet GM et al. (2016) Mid- to late-Holocene environmental evolution of the Loire estuary as observed from sedimentary characteristics and benthic foraminiferal assemblages. Journal of Sea Research 118: 17-34.

Durand M, Mojtahid M, Maillet GM et al. (2018) Late-Holocene record from the Loire incised paleovalley (Bay of Biscay, Northeast Atlantic): Insights into regional and global forcing factors. Palaeogeography, Palaeoclimatology, Palaeoecology 511: 12-28.

Dussud L (2010) CABTEX cruise, RV Pourquoi pas? Sismer. Available at: https://campagnes.flotteoceanographique.fr /campagnes/10030050/.

Estournès G, Menier D, Guillocheau F et al. (2012) The paleoEtel River incised valley on the Southern Brittany inner shelf (Atlantic coast, France): Preservation of Holocene transgression within the remnant of a middle Pleistocene incision? Marine Geology 329-331: 75-92.

Fletcher WJ, Debret M and Goñi MFS (2012) Mid-Holocene emergence of a low-frequency millennial oscillation in western Mediterranean climate: Implications for past dynamics of the North Atlantic atmospheric Westerlies. The Holocene. Available at: http:/hol.sagepub.com/content/early/2012/10/2 5/0959683612460783.

Fontanier C, Jorissen F, Chaillou G et al. (2003) Seasonal and interannual variability of benthic foraminiferal faunas at 550 $\mathrm{m}$ depth in the Bay of Biscay. Deep Sea Research Part I: Oceanographic Research Papers 50(4): 457-494.

Fontanier C, Jorissen F, Licari L et al. (2002) Live benthic foraminiferal faunas from the Bay of Biscay: Faunal density, composition, and microhabitats. Deep Sea Research Part I: Oceanographic Research Papers 49(4): 751-785.

Fontanier C, Mackensen A, Jorissen FJ et al. (2006) Stable oxygen and carbon isotopes of live benthic foraminifera from the Bay of Biscay: Microhabitat impact and seasonal variability. Marine Micropaleontology 58(3): 159-183.

Garcia J, Mojtahid M, Howa H et al. (2013) Benthic and planktic foraminifera as indicators of late glacial to Holocene paleoclimatic changes in a marginal environment: An example from the Southeastern Bay of Biscay. Acta Protozoologica 52: 161-180.

García-Artola A, Stéphan P, Cearreta A et al. (2018) Holocene sea-level database from the Atlantic coast of Europe. Quaternary Science Reviews 196: 177-192.

García-Gallardo Á, Grunert P, Voelker AHL et al. (2017) Reevaluation of the 'elevated epifauna' as indicator of Mediterranean outflow water in the Gulf of Cadiz using stable isotopes (813C, 818O). Global and Planetary Change 155: 78-97.

Garcia-Soto C and Pingree RD (2012) Atlantic Multidecadal Oscillation (AMO) and sea surface temperature in the Bay of Biscay and adjacent regions. Journal of the Marine Biological Association of the United Kingdom 92(2): 213-234.

Golléty C, Riera P and Davoult D (2010) Complexity of the food web structure of the Ascophyllum nodosum zone evidenced by a $\delta 13 \mathrm{C}$ and $\delta 15 \mathrm{~N}$ study. Journal of Sea Research 64(3): 304-312.

Goslin J, Van Vliet Lanoë B, Spada G et al. (2015) A new Holocene relative sea-level curve for western Brittany (France): Insights on Isostatic dynamics along the Atlantic coasts of north-western Europe. Quaternary Science Reviews 129: 341-365.

Govin A, Holzwarth U, Heslop D et al. (2012) Distribution of major elements in Atlantic surface sediments $\left(36^{\circ} \mathrm{N}-49^{\circ} \mathrm{S}\right)$ : Imprint of terrigenous input and continental weathering. Geochemistry, Geophysics, Geosystems 13(1): Q01013.

Guillaud J, Aminot A, Delmas D et al. (2008) Seasonal variation of riverine nutrient inputs in the northern Bay of Biscay (France), and patterns of marine phytoplankton response. Journal of Marine Systems 72(1-4): 309-319.

Häkkinen S and Rhines PB (2004) Decline of Subpolar North Atlantic circulation during the 1990s. Science 304(5670): 555-559. 
Hammer O, Harper DAT and Ryan PD (2001) PAST: Paleontological statistics software package for education and data analysis. Palaeontologia Electronica 4(1): 1-9.

Harlay J, Chou L, De Bodt C et al. (2011) Biogeochemistry and carbon mass balance of a coccolithophore bloom in the northern Bay of Biscay (June 2006). Deep-Sea Research Part I, Oceanographic Research Papers 58(2). Available at: http:// orbi.ulg.ac.be/handle/2268/80279.

Hart MB (2016) Sea grass, maerl, foraminifera and marine conservation. Field Studies Council. Available at: https://fsj.fieldstudies-council.org/.

Hátún H, Sandø AB, Drange $H$ et al. (2005) Influence of the Atlantic Subpolar Gyre on the Thermohaline circulation. Science 309(5742): 1841-1844.

Haug GH, Hughen KA, Sigman DM et al. (2001) Southward migration of the intertropical convergence zone through the Holocene. Science 293(5533): 1304-1308.

Hayward BW, Grenfell HR, Sabaa AT et al. (2010) Using foraminiferal faunas as proxies for low tide level in the estimation of Holocene tectonic subsidence, New Zealand. Marine Micropaleontology 76(1-2): 23-36.

Hurrell JW (1995) Decadal trends in the North Atlantic oscillation: Regional temperatures and precipitation. Science 269(5224): 676-679.

Hurrell JW, Kushnir Y and Visbeck M (2001) The north Atlantic oscillation. Science 291(5504): 603-605.

Hurrell JW, Kushnir Y, Ottersen G et al. (2003) The North Atlantic oscillation: Climatic significance and environmental impact. Geophysical Monograph Series 134: 263-279.

Hurrell JW, Kushnir Y, Ottersen G et al. (2008) The North Atlantic oscillation: Climatic significance and environmental impact. AGU Fall Meeting Abstracts 134: 1244.

Jackson LC, Kahana R, Graham T et al. (2015) Global and European climate impacts of a slowdown of the AMOC in a high resolution GCM. Climate Dynamics 45(11-12): 3299-3316.

Jansen JHF, Van der Gaast SJ, Koster B et al. (1998) CORTEX, a shipboard XRF-scanner for element analyses in split sediment cores. Marine Geology 151(1): 143-153.

Jessen CA, Solignac S, Nørgaard-Pedersen N et al. (2011) Exotic pollen as an indicator of variable atmospheric circulation over the Labrador Sea region during the mid to Late-Holocene. Journal of Quaternary Science 26(3): 286-296.

Johnson SC and Scheibling RE (1987) Structure and dynamics of epifaunal assemblages on intertidal macroalgae Ascophyllum nodosum and Fucus vesiculosus in Nova Scotia, Canada. Marine Ecology Progress Series 37(2-3): 209-227.

Joly D, Brossard T, Cardot H et al. (2010) Les types de climates en France, Une construction spatiale. Cybergeo: European Journal of Geography. Available at: http://cybergeo.revues .org/23155.

Jorissen FJ, de Stigter HC and Widmark JG (1995) A conceptual model explaining benthic foraminiferal microhabitats. Marine Micropaleontology 26(1): 3-15.

Jouanneau JM, Weber O, Cremer M et al. (1999) Fine-grained sediment budget on the continental margin of the Bay of Biscay. Deep Sea Research Part II: Topical Studies in Oceanography 46(10): 2205-2220.

Koutsikopoulos C and Le Cann B (1996) Physical processes and hydrological structures related to the Bay of Biscay anchovy. Scientia Marina 60: 9-19.

Labat D (2008) Wavelet analysis of the annual discharge records of the world's largest rivers. Advances in Water Resources 31(1): 109-117.

Langer M (1988) Recent epiphytic foraminifera from Vulcano (Mediterranean Sea). Revue de Paleobiologie 2: 827-832.

Langer MR (1993) Epiphytic foraminifera. Marine Micropaleontology 20(3): 235-265.
Langer MR and Gehring CA (1993) Bacteria farming; a possible feeding strategy of some smaller motile Foraminifera. The Journal of Foraminiferal Research 23(1): 40-46.

Lazure P and Jégou AM (1998) D modelling of seasonal evolution of Loire and Gironde plumes on Biscay Bay continental shelf. Oceanologica Acta 21(2): 165-177.

Lazure P, Jegou AM and Kerdreux M (2006) Analysis of salinity measurements near islands on the French continental shelf of the Bay of Biscay. Scientia Marina 70(1): 7-14.

Lesueur P, Jouanneau J-M, Boust D et al. (2001) Sedimentation rates and fluxes in the continental shelf mud fields in the Bay of Biscay (France). Continental Shelf Research 21(13-14): 1383-1401.

McCave IN (1972) Transport and escape of fine-grained sediment from shelf areas. In: Swift DJP, Duane D and Pilkey OH (eds) Shelf Sediment Transport. Stroudsburg, PA: Dowden, Hutchinson \& Ross, pp. 225-248.

Madelain F and Kerut E (1978) Evidence of mesoscale eddies in the Northeast Atlantic from a drifting buoy experiment. Oceanologica Acta 1(2): 159-168.

Mangerud J, Bondevik S, Gulliksen S et al. (2006) Marine 14C reservoir ages for 19th century whales and molluscs from the North Atlantic. Quaternary Science Reviews 25(23-24): 3228-3245.

Mann ME, Zhang Z, Rutherford S et al. (2009) Global signatures and dynamical origins of the Little Ice Age and medieval climate anomaly. Science 326(5957): 1256-1260.

Martínez-García B, Pascual A, Rodríguez-Lázaro J et al. (2013) Recent benthic foraminifers of the Basque continental shelf (Bay of Biscay, northern Spain): Oceanographic implications. Continental Shelf Research 66: 105-122.

Mary Y, Eynaud F, Colin C et al. (2017) Changes in Holocene meridional circulation and poleward Atlantic flow: The Bay of Biscay as a nodal point. Climate of the Past 13(3): 201-216.

Milliman JD (2001) Delivery and fate of fluvial water and sediment to the sea: A marine geologist's view of European rivers. Scientia Marina 65(Suppl. 2): 121-132.

Mojtahid M, Jorissen F, Lansard B et al. (2009) Spatial of live benthic foraminifera in the Rhône prodelta: Faunal response to a continental-Marine organic matter gradient. Marine Micropaleontology 70(3-4): 177-200.

Mojtahid M, Jorissen FJ, Garcia J et al. (2013) High resolution Holocene record in the southeastern Bay of Biscay: Global versus regional climate signals. Palaeogeography, Palaeoclimatology, Palaeoecology 377: 28-44.

Mojtahid M, Manceau R, Schiebel R et al. (2015) Thirteen thousand years of southeastern Mediterranean climate variability inferred from an integrative planktic foraminiferal-based approach. Paleoceanography 30(4): 402-422.

Moros M, Andrews John T, Eberl Dennis D et al. (2006) Holocene history of drift ice in the northern North Atlantic: Evidence for different spatial and temporal modes. Paleoceanography 21(2). Available at: https://agupubs.onlinelibrary.wiley.com/ doi/abs/10.1029/2005PA001214.

Morris RKA and Mitchell SB (2013) Has loss of accommodation space in the Humber estuary led to elevated suspended sediment concentrations? Journal of Frontiers in Construction Engineering 2(1): 1-9.

Naughton F, Bourillet JF, Sánchez Goñi MF et al. (2007) Long-term and millennial-scale climate variability in northwestern France during the last 8850 years. The Holocene 17(7): 939-953.

Nizou J, Hanebuth TJJ and Vogt C (2011) Deciphering signals of late-Holocene fluvial and Aeolian supply from a shelf sediment depocentre off Senegal (north-west Africa). Journal of Quaternary Science 26(4): 411-421.

Peterson LC, Haug GH, Murray RW et al. (2000) Late Quaternary stratigraphy and sedimentation at ODP Site 1002, 
Cariaco Basin (Venezuela). In: Proceedings of the ODP Scientific Results, vol. 165 (eds RM Leckie, H Sigurdsson and GD Acton) (Caribbean ocean history and the Cretaceous/Tertiary boundary event: covering Leg 165 of the cruises of the DV 'Joides Resolution', Miami, FA, to San Juan, Puerto Rico, Sites 998-1002, 19 Dec 1995- 15 Feb 1996). College Station, TX: Texas A \& M University Ocean Drilling Program, pp. 85-99. Available at: https://eprints.soton.ac.uk/66109/.

Pingree RD (1984) Some applications of remote sensing to studies in the Bay of Biscay, Celtic sea and English channel. Elsevier Oceanography Series 38: 287-315. Available at: http://www .sciencedirect.com/science/article/pii/S0422989408706172.

Pingree RD and Garcia-Soto C (2014) Plankton blooms, ocean circulation and the European slope current: Response to weather and climate in the Bay of Biscay and W English Channel (NE Atlantic). Deep Sea Research Part II: Topical Studies in Oceanography 106: 5-22.

Pingree RD and Le Cann B (1989) Celtic and Armorican slope and shelf residual currents. Progress in Oceanography 23(4): 303-338.

Pingree RD and Le Cann B (1992a) Anticyclonic eddy X91 in the southern Bay of Biscay, May 1991 to February 1992. Journal of Geophysical Research 979: 14353-14314.

Pingree RD and Le Cann B (1992b) Three anticyclonic slope water Oceanic eDDIES (SWODDIES) in the southern Bay of Biscay in 1990. Deep Sea Research Part A: Oceanographic Research Papers 39(7-8): 1147-1175.

Pisias NG, Dauphin JP and Sancetta C (1973) Spectral analysis of late Pleistocene-Holocene sediments. Quaternary Research 3(1): 3-9.

Pollard RT and Pu S (1985) Structure and circulation of the upper Atlantic Ocean northeast of the Azores. Progress in Oceanography 14: 443-462.

Polyak L, Levitan M, Khusid T et al. (2002) Variations in the influence of riverine discharge on the Kara Sea during the last deglaciation and the Holocene. Global and Planetary Change 32(4): 291-309.

Proust J-N, Menier D, Guillocheau F et al. (2001) Les vallees fossiles de la baie de la Vilaine; nature et evolution du prisme sedimentaire cotier du Pleistocene armoricain. Bulletin de La Société Géologique de France 172(6): 737-749.

Puillat I, Lazure P, Jégou AM et al. (2004) Hydrographical variability on the French continental shelf in the Bay of Biscay, during the 1990s. Continental Shelf Research 24(10): 11431163.

R Core Team (2014) R: A language and environment for statistical computing. Vienna. Available at: http://www.R-project .org/.

Ravelo AC and Hillaire-Marcel C (1999) Chapter Eighteen The Use of Oxygen and Carbon Isotopes of Foraminifera in Paleoceanography. In: Sen Gupta BK (ed.) Modern Foraminifera. Dordrecht: Springer, p. 371. Available at: http://www .sciencedirect.com/science/article/pii/S1572548007010238 . doi:10.1016/S1572-5480(07)01023-8

Reimer PJ, Bard E, Bayliss A et al. (2013) IntCal13 and Marine13 radiocarbon age calibration curves $0-50,000$ years cal BP. Radiocarbon 55(4): 1869-1887.

Rimbu N, Lohmann G, Kim JH et al. (2003) Arctic/North Atlantic oscillation signature in Holocene sea surface temperature trends as obtained from alkenone data. Geophysical Research Letters 30(6): 1280.

Rothwell RG, Hoogakker B, Thomson J et al. (2006) Turbidite emplacement on the southern Balearic Abyssal Plain (western Mediterranean Sea) during Marine Isotope Stages 1-3: An application of ITRAX XRF scanning of sediment cores to lithostratigraphic analysis. GeoLogical Society 267(1): 79-98.
Sarafanov A (2009) On the effect of the North Atlantic oscillation on temperature and salinity of the Subpolar North Atlantic intermediate and deep waters. ICES Journal of Marine Science 66(7): 1448-1454.

Sarafanov A, Mercier H, Falina A et al. (2010) Cessation and partial reversal of deep water freshening in the northern North Atlantic: Observation-based estimates and attribution. Tellus A 62(1): 80-90.

Saraswat R, Kouthanker M, Kurtarkar SR et al. (2015) Effect of salinity induced $\mathrm{pH} /$ alkalinity changes on benthic foraminifera: A laboratory culture experiment. Estuarine, Coastal and Shelf Science 153: 96-107.

Saraswat R, Nigam R and Pachkhande S (2011) Difference in optimum temperature for growth and reproduction in benthic foraminifer Rosalina globularis: Implications for paleoclimatic studies. Journal of Experimental Marine Biology and Ecology 405(1-2): 105-110.

Schmidt DN, Renaud S, Bollmann J et al. (2004) Size distribution of Holocene planktic foraminifer assemblages: Biogeography, ecology and adaptation. Marine Micropaleontology 50(3-4): 319-338.

Schmittner A, Bostock HC, Olivier C et al. (2017) Calibration of the carbon isotope composition $(\delta 13 \mathrm{C})$ of benthic foraminifera. Paleoceanography 32(6): 512-530.

Schulz M, Prange M and Klocker A (2007) Low-frequency oscillations of the Atlantic Ocean meridional overturning circulation in a coupled climate model. Climate of the Past 3(1): 97-107.

Sharples J, Moore CM, Hickman AE et al. (2009) Internal tidal mixing as a control on continental margin ecosystems. Geophysical Research Letters 36(23): L23603.

Sherwin TJ, Read JF, Holliday NP et al. (2012) The impact of changes in North Atlantic Gyre distribution on water mass characteristics in the Rockall Trough. ICES Journal of Marine Science 69(5): 751-757.

Shorthouse CA and Arnell NW (1997) Spatial and temporal variability in European river flows and the North Atlantic oscillation. FRIEND '97-Regional Hydrology: Concepts and Models for Sustainable Water Resource Management. In: Proceedings of the Postojna, Slovenia, Conference, Postojna, September-October, pp. 77-85. Postojna: IAHS Publication.

Sliter WV (1965) Laboratory experiments on the life cycle and ecologic controls of Rosalina globularis d'Orbigny. The Journal of Protozoology 12(2): 210-215.

Solignac S, de Vernal A and Hillaire-Marcel C (2004) Holocene sea-surface conditions in the North Atlantic-contrasted trends and regimes in the western and eastern sectors (Labrador Sea vs. Iceland Basin). Quaternary Science Reviews 23(3-4): 319-334.

Solomina ON, Bradley RS, Hodgson DA et al. (2015) Holocene glacier fluctuations. Quaternary Science Reviews 111: 9-34.

Soon W, Velasco Herrera VM, Selvaraj K et al. (2014) A review of Holocene solar-linked climatic variation on centennial to millennial timescales: Physical processes, interpretative frameworks and a new multiple cross-wavelet transform algorithm. Earth-Science Reviews 134: 1-15.

Sorrel P, Debret M, Billeaud I et al. (2012) Persistent non-solar forcing of Holocene storm dynamics in coastal sedimentary archives. Nature Geoscience 5(12): 892-896.

Spencer CD, Plater AJ and Long AJ (1998) Rapid coastal change during the mid- to Late-Holocene: The record of barrier estuary sedimentation in the Romney Marsh region, southeast England. The Holocene 8(2): 143-163.

Staines-Urías F, Kuijpers A and Korte C (2013) Evolution of subpolar North Atlantic surface circulation since the early Holocene inferred from planktic foraminifera faunal and 
stable isotope records. Quaternary Science Reviews 76: 66-81.

Stiger-Pouvreau V, Jégou C, Cerantola S et al. (2014) Phlorotannins in sargassaceae species from brittany (France): Interesting molecules for ecophysiological and valorisation purposes. Advances in Botanical Research 71: 379-411.

Stuiver M, Braziunas TF, Grootes PM et al. (1997) Is there evidence for solar forcing of climate in the GISP2 oxygen isotope record? Quaternary Research 48(3): 259-266.

Sutton RT and Hodson DLR (2005) Atlantic ocean forcing of North American and European summer climate. Science 309(5731): 115-118.

Ters M, Planchais N and Azema C (1968) L'évolution de la basse vallée de la Loire, à l'aval de Nantes, à la fin du Würm et pendant la transgression flandrienne. Bulletin de L'association Française Pour L'étude Du Quaternaire 5(3): 217-246.

Thompson LG, Mosley-Thompson E, Davis ME et al. (2003) Tropical glacier and ice core evidence of climate change on annual to millennial time scales. Climatic Change 59(1): $137-155$

Thornalley DJ, Elderfield H and McCave IN (2009) Holocene oscillations in temperature and salinity of the surface subpolar North Atlantic. Nature 457(7230): 711-714.

Tjallingii R, Röhl U, Kölling M et al. (2007) Influence of the water content on X-ray fluorescence core-scanning measurements in soft marine sediments. Geochemistry, Geophysics, Geosystems 8(2). Available at: https://agupubs.onlinelibrary. wiley.com/doi/abs/10.1029/2006GC001393.

Traini C, Proust J-N, Menier D et al. (2015) Distinguishing natural evolution and human impact on estuarine morpho-sedimentary development: A case study from the Vilaine Estuary, France. Estuarine, Coastal and Shelf Science 163: 143-155.

Tréguer P, Goberville E, Barrier N et al. (2014) Large and localscale influences on physical and chemical characteristics of coastal waters of Western Europe during winter. Journal of Marine Systems 139: 79-90.

van Maren DS, Oost AP, Wang ZB et al. (2016) The effect of land reclamations and sediment extraction on the suspended sediment concentration in the Ems Estuary. Marine Geology 376: 147-157.

Van Vliet-Lanoë B, Penaud A, Hénaff A et al. (2014) Middleto late-Holocene storminess in Brittany (NW France):
Part II - The chronology of events and climate forcing. The Holocene 24(4): 434-453.

Vincent A and Kurc G (1969) Hydrologie.Variations saisonnières de la situation thermique du golfe de gascogne en 1967. Revues Travaux Institut Pêches Maritimes 33(1): 79-96.

Visset L, Cyprien A-L, Carcaud N et al. (2002) Les prémices d'une agriculture diversifiée à la fin du Mésolithique dans le Val de Loire (Loire armoricaine, France). Comptes Rendus Palevol 1(1): 51-58.

Wanner H, Beer J, Bütikofer J et al. (2008) Mid- to Late-Holocene climate change: An overview. Quaternary Science Reviews 27(19-20): 1791-1828.

Weber O, Jouanneau JM, Ruch P et al. (1991) Grain-size relationship between suspended matter originating in the Gironde estuary and shelf mud-patch deposits. Marine Geology 96(1): 159-165.

Weltje GJ and Tjallingii R (2008) Calibration of XRF core scanners for quantitative geochemical logging of sediment cores: Theory and application. Earth and Planetary Science Letters 274(3): 423-438.

Wollast R and Chou L (2001) The carbon cycle at the ocean margin in the northern Gulf of Biscay. Deep Sea Research Part II: Topical Studies in Oceanography 48(14): 3265-3293.

Xiang R, Yang Z, Saito Y et al. (2008) Paleoenvironmental changes during the last 8400 years in the southern Yellow Sea: Benthic foraminiferal and stable isotopic evidence. Marine Micropaleontology 67(1): 104-119.

Yong-Qi G and Lei Y (2008) Subpolar Gyre index and the North Atlantic Meridional overturning circulation in a coupled climate model. Atmospheric and Oceanic Science Letters 1(1): 29-32.

Ziegler M, Jilbert Tom de Lange Gert J, Lourens Lucas J et al. (2008) Bromine counts from XRF scanning as an estimate of the marine organic carbon content of sediment cores. Geochemistry, Geophysics, Geosystems 9(5). Available at: https:// agupubs.onlinelibrary.wiley.com/doi/full/10.1029/2007GC00 1932.

Zumaque J, Eynaud F and de Vernal A (2017) Holocene paleoceanography of the Bay of Biscay: Evidence for westeast linkages in the North Atlantic based on dinocyst data. Palaeogeography, Palaeoclimatology, Palaeoecology 468: 403-413. 